\title{
A Ação do Govêrno na Administração de Pessoal *
}

GLAUCO LESSA DE ABREU E SILVA

Diretor-Geral do DASP

\section{Senhor Presidente}

\section{Senhores Deputados:}

Após 33 anos de existência, sempre dominado pela preocupação de proporcionar ao Govêrno e ao País uma contribuição positiva no roteiro da modernização e do desenvolvimento, vem - DASP, por primeira vez, manter diálogo com esta alta Comissão Técnica do Congresso Nacional.

Reveste-se, assim, de marcante significação o convite, realmente desvanecedor, ensejando-nos a exposiçăo que vamos fazer a Vossas Excelências.

Não seria oportuno nem adequado, nos limites preestabelecidos desta exposição deliberadamente esquemática e destituída de atavios literários, quaisquer exageros de teorização, tratamento acadêmico ou formulaçöes sofisticadas.

Pretendemos expor concisamente, sem retórica, e, sempre que possivel, em têrmos de apreciação quantitativa e grática, os delineamentos de uma Política dinâmica de pessoal que pode e deve ser conceituada como uma componente estratégica básica do desenvolvimento nacional.
Evidentemente, a concepção e definição das linhas gerais da nova Politica, que o Govêrno de Sua Excelência - Presidente Emílio Garrastazu Médici vem enérgica e corajosamente levando a efeito, podem ser mais bem compreendidas quando confrontadas com os ensinamentos oriundos da experiência brasileira nos domínios da Administração de Pessoal no Serviço $\mathrm{Cl}$ vil da União.

Releva acentuar que, no decorrer desta década, a trajetória da Administração sofreu o impacto de transformações decisivas, decorrentes da expansão verificada em tôdas as áreas, setores e niveis da vida do País, tanto no âmbito das Unidades da Federação, como verticalmente no tocante à aceleração do incoercivel ritmo do progresso nacional, revelado pelos indicadores e coeficientes das estatisticas demográficas, econômicas e sociais.

Nesse contexto, empenha-se o Govêrno em elaborar uma Política de

* Exposiçăo feita perante a Comissăo de Serviço Público da Camara dos Deputados, em 14 de outubro de 1971. 
Pessoal realista, equacionada em função e a serviço dos objetivos prioritários, traduzidos no volume considerável de projetos que integram o Plano Nacional de Desenvolvimento, recém-submetido pelo Excelentíssimo Senhor Presidente da República ao exame do Congresso Nacional.

Neste sentido, tanto "As Metas e Bases para a Ação de Govêrno" como - "Plano Nacional de Desenvolvimento" acentuaram a essencialidade de criarem-se condições favoráveis a "uma atuação dinâmica e planejada do serviço "público federal" como preliminar fundamental, de vez que os contingentes de servidores constituem a fôrça de trabalho sem a qual os planos, projetos e atividades programados permaneceriam no papel, sem condiçōes de exeqüibilidade. Sem um tratamento arrojado e - por que não dizer - verdadeiramente revolucionário dos recursos humanos necessários, a Administração Pública se diluiria pelo funcionamento desarticulado dos órgãos que a integram, sem lograr aquelas condições de capacitação funcional, eficiência, motivação e produtividade indispensáveis ao pleno sucesso dos grandes empreendimentos programados.

Podemos afirmar, sem receio de contestação, já ter sido deflagrado um esquema de providências que, devidamente entrosadas, importam em radical transformação institucional destinada a proporcionar ao Govêrno meios e instrumentos de ação válidos, oportunos e práticos e que, no conjunto, se apresentam como os alicerces $e$ parâmetros da nova Política que vem sendo gradualmente implantada.
Na seqüência cronológica dos diplomas legais que a configuram, as providências em andamento consubstanciam uma Política sensata, diretamente emanada dos princípios da Reforma Administrativa. Contudo, a exeqüibilidade dos aludidos diplomas vem exigindo esforços excepcionais visando à correção de distorções de tôda espécie e ao desemperramento das estruturas burocráticas.

Urgia descongestionar setores estagnados, com a adoção de medidas saneadoras preliminares, e promover a descentralização imprescindivel.

A simples enumeração das iniciativas do Govêrno no concernente ao delineamento da nova Política e à programação operativa em andamento demonstra que vão sendo definitivamente erradicados o empirismo e a improvisação no que diz respeito à $\mathrm{Admi-}$ nistração de Pessoal.

O Govêrno conseguiu, indiscutivelmente, delinear e pôr em execução as soluções mais convenientes às exigências nacionais nesta fase de nossa evolução histórica.

A partir da Comissão de Reforma do Pessoal Civil, instituida pelo Decreto $n^{\text {? }}$ 64.335 , de 9 de abril de 1969, teve início um processo irreversivel de tomada de decisöes, que poderiamos cronològicamente condensar no seguinte conjunto de providências:

1. Transferência aos órgãos de Pessoal dos Ministérios e das Autarquias da responsabilidade pela solução dos processos de enquadramentos e readaptações, sob a supervisão, coordenação e contrôle do DASP (Decreto-lei n? 625 , de 11 de junho de 1969). 
2. Estruturação de um Sistema de Cadastro dos Servidores Civis da Administração Federal (Decreto $n$ ? .... 64.564 , de 22 de maio de 1969).

3. Execução descentralizada do recrutamento e da seleção de pessoal civil na Administração Federal Direta e Autarquias de maior porte, a juizo do Poder Executivo (Decreto-lei n? 797, de 27 de agôsto de 1969).

4. Reorganização do DASP mediante implantação de uma estrutura atualizada que o configura como órgão Central do Sistema de Pessoal para o "estudo, proposição de diretrizes, orientação, coordenação, supervisão e contrôle dos assuntos concernentes à Administração do Pessoal Civil" (Decreto $n$ \% 66.222, de 17 de fevereiro de 1970).

5. Organização do Sistema de Pessoal Civil da Administração Federal (SIPEC) como decorrência das recomendações do Decreto-lei $n \div 200$, de 1967 (Decreto n? 67.326, de 5 de outubro de 1970).

6. Estabelecimento do Plano para execução da Política Salarial do Serviço Civil do Poder Executivo (Decreto no 67.561 , de 12 de novembro de 1970).

7. Disciplinação do Assessoramento Superlor da Administração Civil Federal (Decreto $n$ \% 67.612, de 19 de novembro de 1970).

8. Fixação das Diretrizes para a Classificação de Cargos do Serviço Civil da União $\theta$ das Autarquias $\mathrm{Fe}$ derais (Lei $n$ : 5.645, de 10 de dezembro de 1970).

9. Constituição e funcionamento das Equipes Técnicas de Alto Nivel de que trata $\circ$ art. 11 da Lei $n$ ? 5.645 , de 10-12-70 (Decreto $n$ \% 68.726, de 9 de junho de 1971).

10. Elaboração e registro da lotação de cargos e empregos dos órgãos da Administração Direta e das Autarquias (Decreto $n$ \% 68.991, de 28 de julho de 1971).

11. Instituição da Auditoria nos Órgãos integrantes do Sistema de Pessoal Civil da Administração Federal (SIPEC). (Decreto n? 68.992, de 28 de julho de 1971.)

Examinaremos, a seguir, as medidas governamentais básicas que definem a ação do Govêrno e, simultâneamente, estabelecem a instrumentalidade imprescindivel ao Poder Executivo para o desempenho, em altos niveis de eficiência e funcionalidade operacional, dos encargos e responsabilidades que traduzem concretamente a sua atuação na esfera da Administração do Pessoal Civil da União.

ACELERAMENTO DO SISTEMA VIGENTE. ENUMERAÇAOO DAS PROVIDENCIAS TOMADAS. RESULTADOS. MEDIDAS PRELIMINARES AO NÖVO PLANO DE CLASSIFICAÇAO DE CARGOS. DESCENTRALIZAÇÃO

A expediçăo do Decreto-lel $n$ ? 625 , de 11 de junho de 1969, resultou, primordialmente, da necessidade de resolver, em consonância com os impositivos da descentralização preconizados pela Reforma Administrativa, os complexos problemas de enquadramentos e readaptações ainda pendentes e que se traduziam em um vclume considerável de trabalhos até então centralizados no DASP. 
O deferimento de maior competência - e responsabilidades correspondentes - às unidades de pessoal dns Ministérios e das Autarquias tornara-se imperioso como pré-condição para o desemperramento de todo o Sistema.

Dentro dessa orientação, impunha-se promover o acionamento necessário junto aos órgãos de Pessoal, objetivando a mais rápida solução daqueles processos.

Vejamos os resultados dessa descentralização. (Gráficos)

Esses números ressaltam a quantidade de servidores readaptados a partir de 1964 e até 11 de junho de 1969 , totalizando 37.839 num período de mais ou menos 5 anos e meio. Em contrapartida, no período que medeia entre $12-6-69$ e 31-8-71, ou sejam 2 anos aproximadamente, já na vigência do Decreto-lei $n$ ? 625 , de 1969 , atingiu-se o total de 26.076 servidores.

Os enquadramentos efetuados pelo DASP no regime anterior de centralização atingiram o total de 192.232 servidores, entre 1964 e meados de 1969 , ou seja, em aproximadamente 5 anos e meio.

$\mathrm{Na}$ vigência do Decreto-lei $n$ ? 625 , de 1969, citado, até 31 de agôsto de 1971 - em dois anos - obteve-se o resultado de 167.357 servidores enquadrados.

Ficaram assim resolvidos os problemas de readaptação e enquadramento, sendo insignificante o número de casos remanescentes - fato êsse que comprova 0 acêrto e as vantagens da descentralização adotada.
Além dessas realizações positivas, vem o Govêrno enfatizando a unificação das Partes Permanentes e Especiais dos Quadros de Pessoal dos órgãos da Administração Direta e das Autarquias, a fim de possibilitar a promoção mais rápida de servidores, em face da abertura de vagas nas classes superiores das séries de classes que compõem tais Quadros.

Para tanto, traçamos normas com a finalidade de facilitar a execução dêsses trabalhos pelos órgãos interessados, sem falar na assistência permanente que, por intermédio de nossa equipe de técnicos, prestamos aos setores de classificação de cargos daquelas repartições.

\section{PARIDADE}

Com relação ao desenvolvimento das atividades ligadas ao sistema de retribuição, cabe acentuar a atuação do Govêrno com vistas à implantação da paridade na área do Poder Executivo, principalmente no que se refere aos empregos e funções integrantes de quadros e tabelas das Autarquias $\mathrm{Fe}^{-}$ derais regidos pela legislação trabaIhista. É nessa área, de resto, que se situam, em boa parte, as distorçóes salariais existentes na Administração Federal.

Levando-se em conta a conveniência de não agravar as mencionadas distorções salariais, deixou-se de aplicar ao pessoal referido o Decreto-lei $n$ ? 1.073 , de 9 de janeiro de 1970 , que reajustou os vencimentos dos servidores civis e militares do Poder Executivo, até que se encontrasse uma $\mathrm{so}^{-}$ lução compativel com a obediência ao preceito constante dos artigos 98 e 108 da Constituição. 

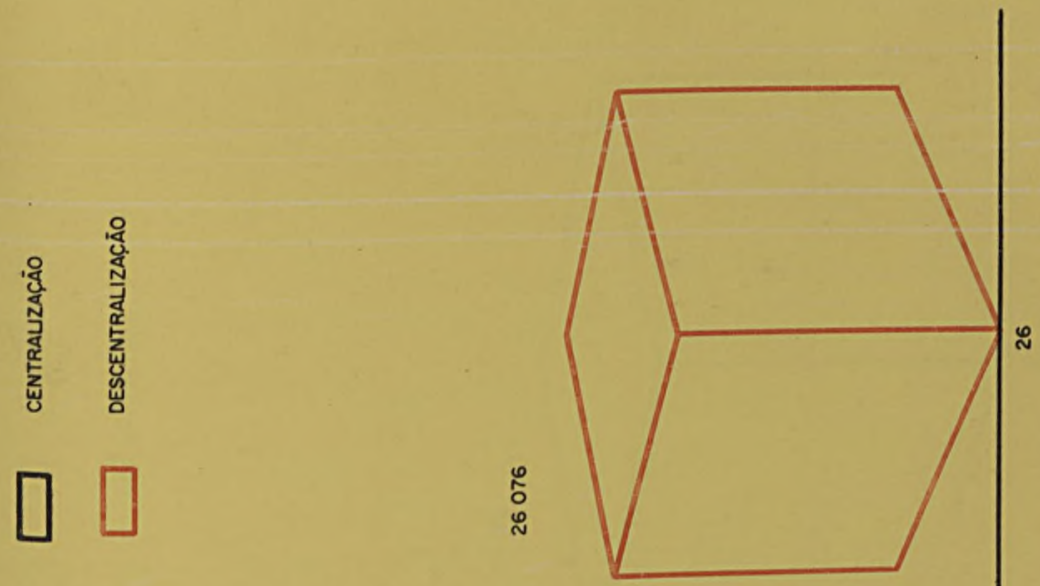

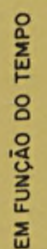
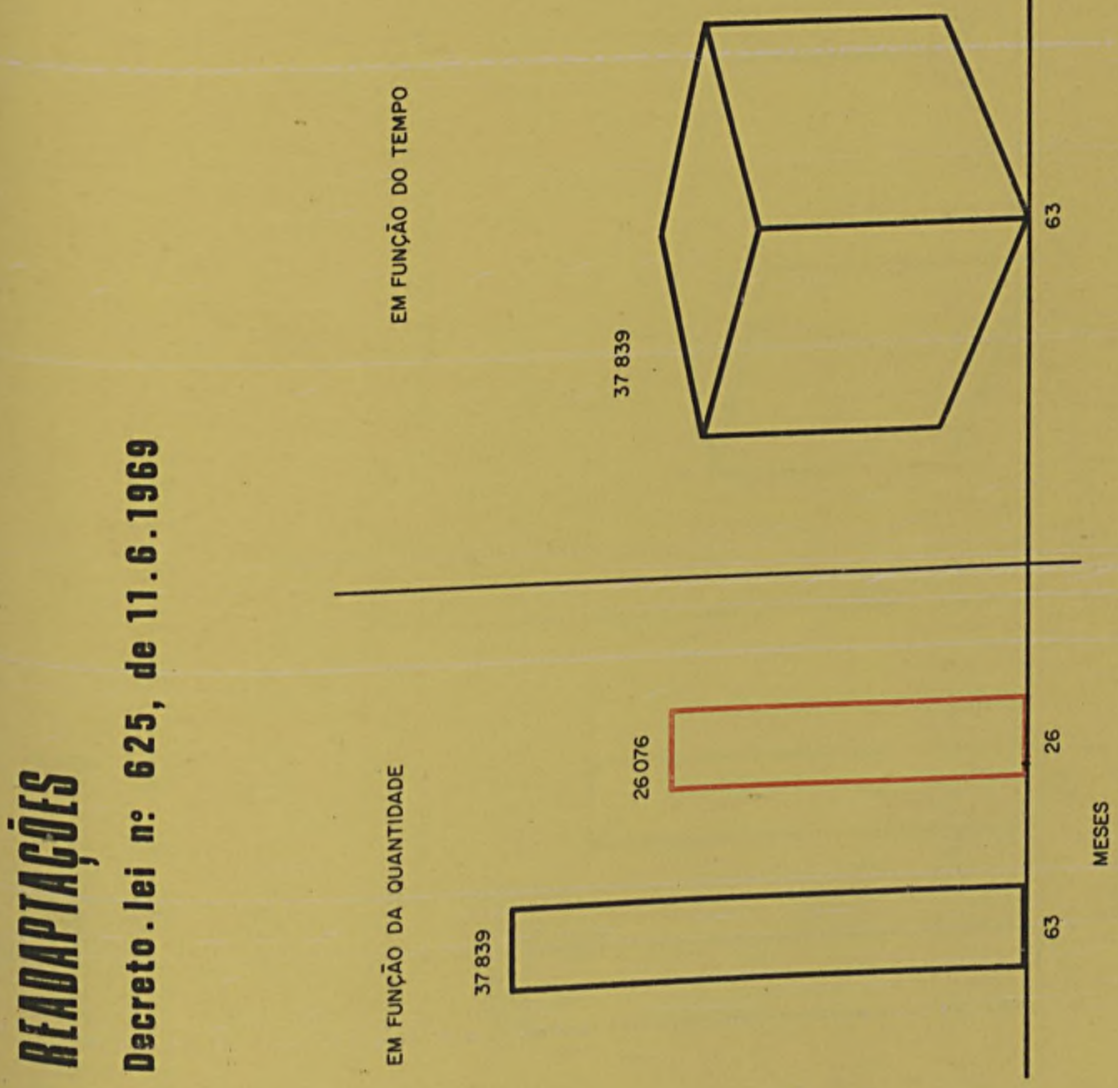


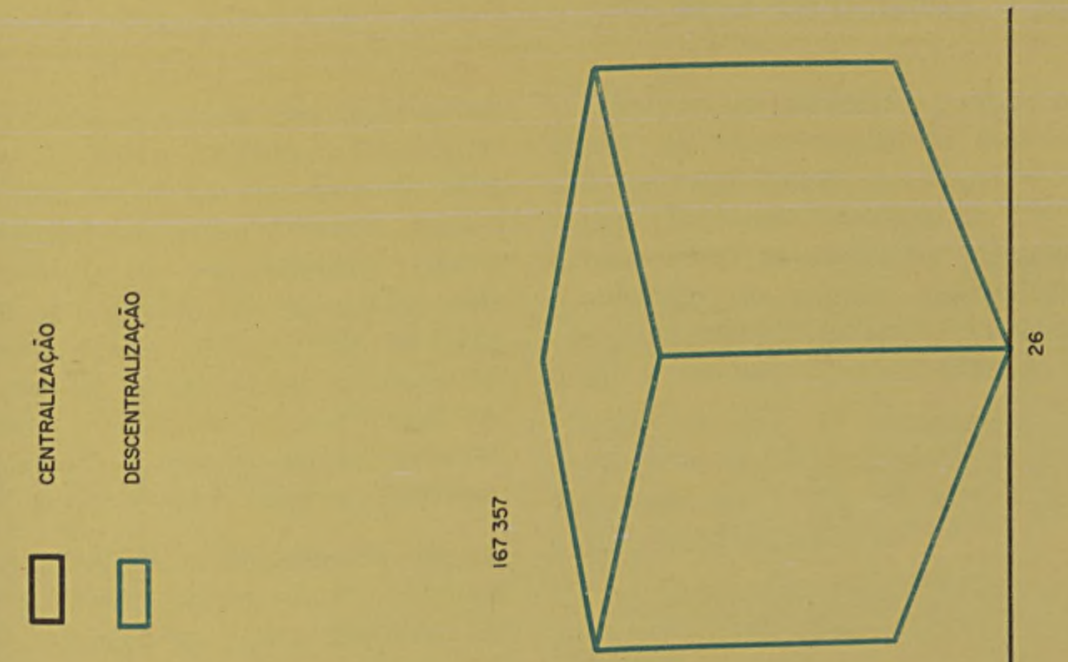

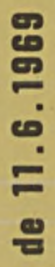
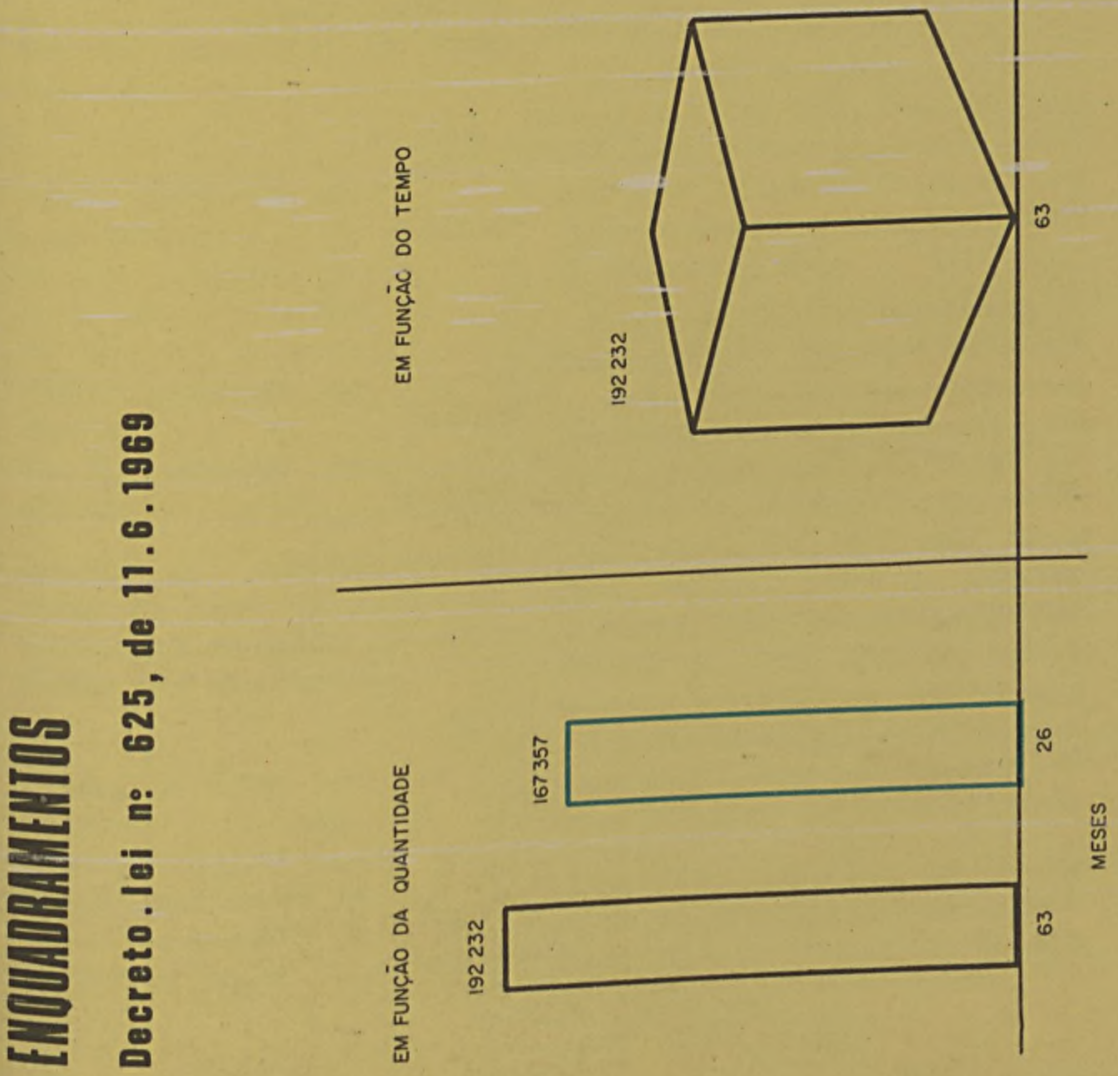

De acôrdo com a orientação adota$\mathrm{da}$, foi, então, baixado o Decreto $n$ ? 67.678 , de 30 de novembro de 1970 , estabelecendo nôvo processo para a concessão do reajustamento salarial aos empregados não abrangidos pelo Decreto-lei $n$ : 1.073, de 1970, de modo a não ser concedido, em nenhuma hipótese, aumento superior ao fixado para cargos e funções correspondentes do Serviço Público Federal. (Gráfico)

A aplicação da mecânica de que trata o Decreto número $67.678 / 70$ pode ser resumida da forma seguinte, tomando-se como exemplo unidade organizacional ligada ao desenvolvimento regional:

- Emprêgo com a mesma denominação de cargo existente na sistemática de classificação do Poder Executivo:

$\mathrm{Cr} \$$

Salário anterior do emprêgo de Médico ....... Aumento concedido pelo Decreto-lei $n$ : 1.073 , de 1970, ao cargo de Médico classificado no nível $22 \ldots \ldots \ldots \ldots$.

Salário reajustado do emprêgo de Médico $\ldots \quad 2.097,31$

- Emprêgo sem identidade de denominação com qualquer cargo existente na sistemática de classificação do Poder Executivo:

Emprêgo de Auxiliar Administrativo (o de maior salário existente no grupamento considerado de nivel administrativo e serviços auxiliares) .....
Tomou-se por paradigma o cargo de Oficial de Administração da sistemática de classificação do Poder Executivo, classificado no nivel 12 , a que correspondem as atividades inerentes a emprêgo do referido grupamento, como determina o parágrafo único do artigo $1^{\circ}$ do Decreto $n \div 67.678$.

Como ao nivel 12 correspondeu o aumento de $\mathrm{Cr} \$ 61,92$ concedido pelo Decreto-lei $n$ ? 1.073 , foi feita a seguinte proporcionalidade:

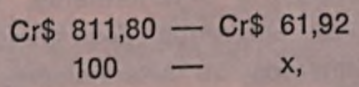

encontrando-se o percentual de $7,6 \%$ que foi aplicado aos salários mensais de todos os empregos do grupamento de nivel administrativo e serviços auxiliares.

O emprêgo de Auxiliar Administrativo teve, dêsse modo, um aumento de $\mathrm{Cr} \$ 61,92$, passando o salário reajustado a ser de $\mathrm{Cr} \$ 873,72$ mensais, obtendo os demais o mesmo percentual de aumento $(7,6 \%)$.

Essa mecânica foi incorporada ao Decreto-lei $n \div 1.150$, de 3 de fevereiro do ano em curso, que reajustou os vencimentos dos servidores civis e militares, atingindo cêrca de $20.982 \mathrm{em}$ pregados dos seguintes órgãos: DNER, CNEN, EMFA, IBC, CLM, IBDF, UF do Pará, INCRA, SUDECO, DENTEL, SUFRAMA, SUDESUL, SUDAM, SUSEP, GERAN, SUDENE, APRJ e Agência Nacional, resultando em aumentos que, em têrmos percentuais, variaram, aproximadamente, entre $6 \%$ (seis por cento) e $12 \%$ (doze por cento). (Gráfico)

Verifica-se que, com tal procedimento, os empregos efetivos de maior 811,80 classificação de uma dessas unidades 
ficaram com o salário atual de Cr\$ .. $2.772,00$ após os reajustamentos decorrentes do Decreto $n$ ? 67.678 , de 1970, e do Decreto-lei n? 1.150 , de 1971 ; os de melhor classificação no nivel médio estão com o salário de Cr\$ 1.241,00; e os de nível administrativo, com Cr\$ 871,00 . Caso fôsse aplicado o critério geral estabelecido pelos referidos diplomas, isto é, a concessão pura e simples do aumento percentual de $20 \%$ (vinte por cento), como ocorria anteriormente, teríamos para os empregos dos mencionados grupamentos os salários mensais de Cr $\$ 3.525,00$, Cr $\$ 1.549,00$ e $\mathrm{Cr} \$ \ldots$ $1.058,00$, respectivamente, $\circ$ que agravaria, sensivelmente, as distorções salariais, quando é sabido que os vencimentos fixados para os cargos enquadrados naqueles grupamentos, na escola vigente no Poder Executivo, têm valôres bem menores, considerando-se, inclusive, a gratificação pelo regime de tempo integral e dedicação exclusiva, isto é: $\operatorname{Cr} \$ 1.943,00$ (para nível superior); $\operatorname{Cr} \$ 1.117,00$ (para o nivel médio) e Cr $\$ 602,00$ (para o nivel auxiliar).

O prosseguimento do Plano de política salarial adotado pelo Govêrno facilitará, sem dúvida, a implantação do nôvo Sistema de Classificação de Cargos e Empregos, de que trata a Lei no 5.645 , de 10 de dezembro de 1970, possibilitando, outrossim, uma forma de pagamento em bases iguais para atribuições iguais, como preconizado na Lei Maior.

CADASTRO

Uma das maiores deficiências verificadas no Serviço Público Brasileiro, com reflexos negativos nos vários setores de atuação da quase totalidade dos Órgãos da Administração Direta e Indireta, sempre foi a ausência de cadastros permanentemente atualizados, em condições de permitir aos administradores ou responsáveis pela execução dos serviços o conhecimento exato, preciso e oportuno das situaçöes reais no concernente a cada caso concreto.

O levantamento de dados fidedignos por meio do Subsistema de Cadastro - Lotação, coordenado pelo DASP, possibilitará o contrôle da realidade, a formulação de diagnósticos válidos e das melhores soluções para os diversos problemas ocorrentes e - 0 que é ainda mais importante - ensejará o embasamento da nova Política de Pessoal em alicerces de solidez incontestável.

Daí a essencialidade do Decreto $n^{\circ}$. 64.564 , de 22 de malo de 1969 , que assegurou a possibilidade de obtenção de informações realmente merecedoras de confiança, disciplinando o processo de sua obtenção mediante os levantamentos numéricos de interêsse prioritário para o Órgão Central do Sistema de Pessoal, bem como dos levantamentos nominais pelos órgãos Setoriais, ou de quaisquer outras modalidades de levantamentos em bases permanentes, ao contrário dos censos periódicos, que năo permitiram respostas prontas e rigorosamente exatas às indagações formuladas. Empreendimento essencialmente técnico quanto à sua concepção e execução, a funçăo primordial do cadastro é, certamente, a de proporcionar segurança e objetividađe ao processo decisório das autoridades responsáveis pela tomada das providências básicas no campo da Administração de Pessoal, notadamen- 

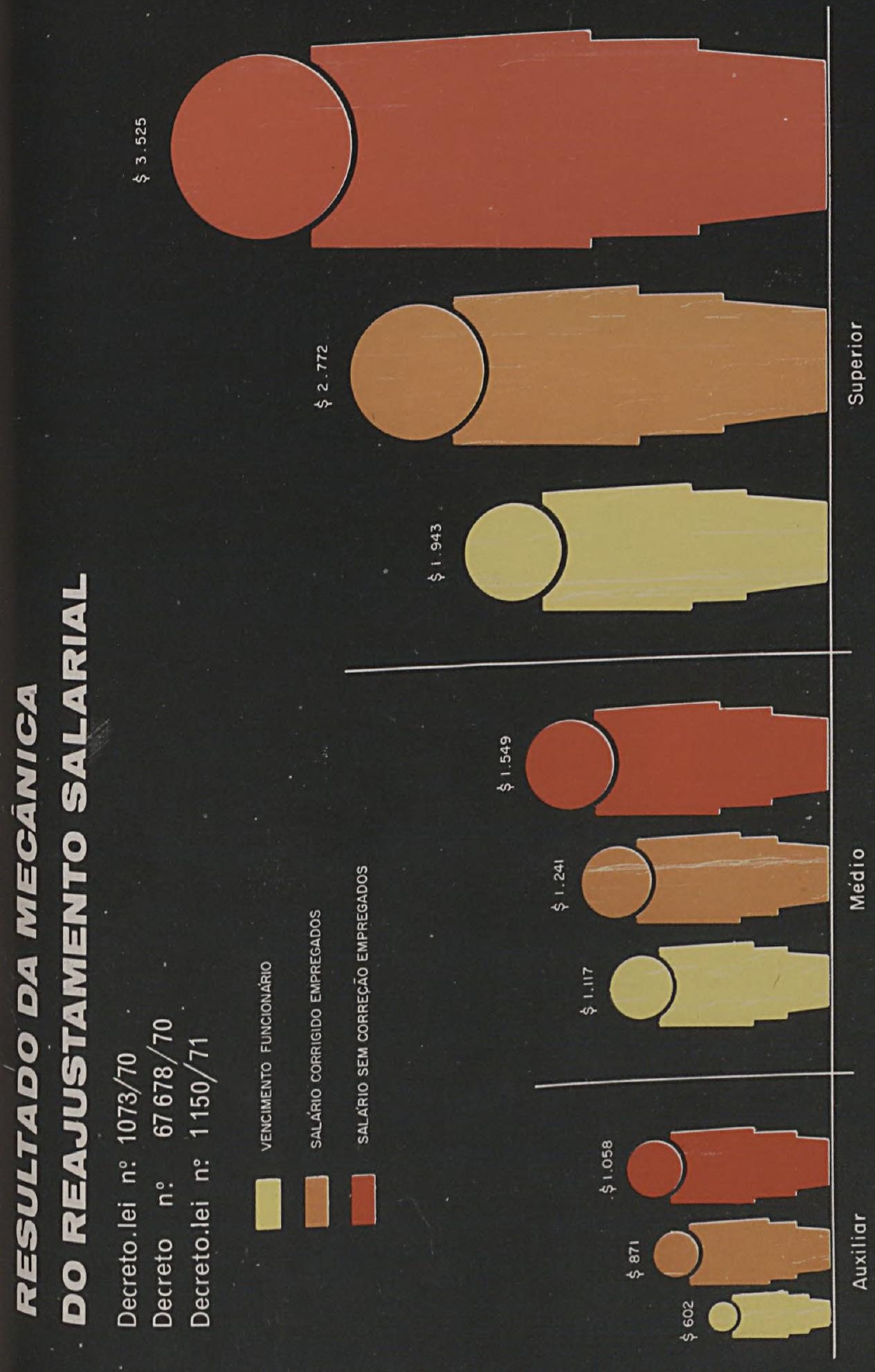



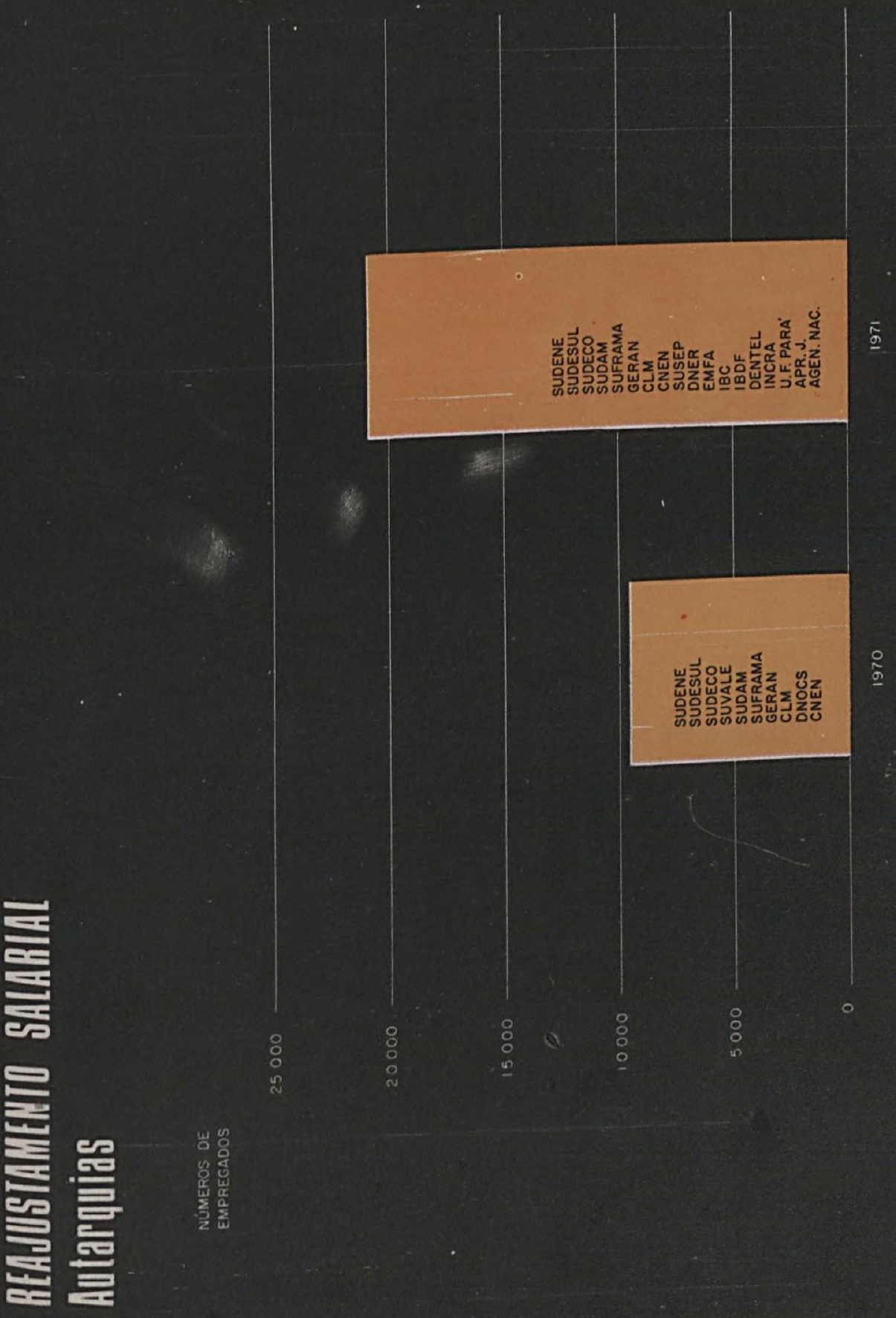



te as que envolvem compromissos de ordem financeira, administrativa, técnica ou predominantemente jurídica.

Estudos realizados levaram à opção pela implantação de um cadastro automatizado. Esperamos instalar, em breve, equipamento adequado à realização dos trabalhos pertinentes.

Os gráficos a seguir bastam para proporcionar uma visão de conjunto a respeito do panorama atual do Serviço Público Brasileiro. O Cadastro vale pràticamente como uma tradução, em têrmos quantitativos, da realidade nacional quanto à fôrça de trabalho em atividade, sua composição, distribuição, denominação e custos. (Gráficos)

\section{INSTRUMENTALIDADE DA REFORMA REORGANIZAÇÃO DO DASP}

As profundas transformações por que - DASP vem passando depois da expedição do Decreto $n^{\circ} 66.222$, de 22 de fevereiro de 1970 - que reformulou integralmente suas diretrizes de atuação e deu-lhe uma estrutura compativel com as exigências do funcionamento racional da Administração $\mathrm{Fe}$ deral - capacitaram-no para o desempenho de sua missão prioritária como Órgão de assessoramento especializado do Chefe do Poder Executivo, incumbido do estudo, elaboração de normas, coordenação, orientação, supervisão e contrôle dos assuntos concernentes à Administraçăo do Pessoal Civil. (Gráfico)

A ampla reforma promovida nos têrmos do aludido Decreto foi a mais importante e radical no decorrer da história da instituição, que passou efetivamente a funcionar como dínamo propulsor da modernização administrativa colimada pelo Govêrno.
Conforme esclareceu um dos mais lúcidos estudiosos das realidades brasileiras, "trata-se de uma concepção organizacional perfeitamente lógica e altamente eficaz para a concretização de projetos. Não obstante ter-se operado há apenas alguns meses, a modernização do DASP já vem mostrando malor rendimento de trabalho.

E isto está acontecendo ainda na delicada faixa transicional gerada pelo ajuste estrutura antiga/estrutura nova".

São variadas e bastante sugestivas as consequeências práticas do modêlo adotado, que foi definido como uma "Organização Estruturada em funçăo de Projetos", ou seja, consoante resumiu aquêle estudioso, um tipo de organização que se poderia identificar pela sigla ORPRO, a qual tem revelado inúmeras vantagens tais como:

I - Adaptabilidade e Maneabilidade;

II - Estrutura plana e cadeia de comando curta;

III - Execução cabal dos objetivos do órgão;

IV - Institucionalização do planejamento e das projeções especificas;

V - Trabalho ininterrupto;

VI - Redução de custos operacionais;

VII - Emprêgo efetivo e racional da mão-de-obra existente;

VIII - Velocidade máxima nas comunicações;

IX - Trabalho cronogramado;

$X$ - Coesão interpessoal dos Grupos-Tarefa;

$\mathrm{XI}$ - Funcionalidade em ponto-ótimo;

XII - Resultados positivos. 
As estatísticas dos resultados obtidos na exigüidade do prazo decorrido demonstram que estamos no caminho certo.

O Centro de Documentação e Informática - A institucionalização do DASP, como Órgão Central do Sistema de Pessoal Civil, teve repercussöes imediatas na área do Serviço de Documentação, sucedido pelo Centro de Documentação e Informática ........ (CENDOC). A função precípua daquele antigo Serviço ampliou-se consideràvelmente com a criação do Centro, cujos objetivos tendem a transformálo numa central de informações, destinada a levar aos órgãos integrantes do SIPEC orientação de caráter normativo, que thes permita atingir uma visão dinâmica dos preceitos legais concernentes à Administração do Pessoal no Serviço Público Civil da União.

A tarefa de tornar acessivel a informação básica de que carecem os órgãos Setoriais do SIPEC exige a execução simultânea de duas atividades essenciais: a) a coleta, a ordenação e sistematização dos preceitos legais na área de pessoal; e b) regular a pronta distribuição dêsse dados. $O$ volume, a variedade e amplitude dos elementos a serem coletados e distribuídos apontam, evidentemente, a imprescindibilidade de emprêgo da moderna técnica de computação eletrônica de dados. Entre a utilização dêsse sistema e a divulgação assistemática-empírica, optamos por uma escala progressiva, cuja etapa preliminar se encontra em fase avançada de execução. (Gráfico)

A instituição do Boletim Diretrizes Legislação e Orientação Administrativa (Portaria $n$ : 240, de 27-6-69) consistiu na primeira iniciativa adotada, através da qual teve início a coleta, a sistematização e a distribuição do que poderíamos chamar - em sentido lato - a "jurisprudência administrativa" aplicável à administração do pessoal, no Serviço Público Civil. A codificação, a classificação e a indexação da vasta matéria disponivel começaram a ser enfrentadas de maneira experimental, com o objetivo de solucionar êsse problema básico da computação que é, exatamente, o maior obstáculo para o emprêgo imediato dos modernos métodos de automação. Correlacionada com essas tarefas, surgiu a idéia de consolidar as normas em vigor na área de pessoal - embora ainda por métodos tradicionais - visando à sua reunião e sistematização num manual para consultas. Trabalho de tal magnitude, entretanto, sòmente poderá chegar a têrmo se viável a efetiva colaboração dos órgãos integrantes do SIPEC. Da experiência colhida, será possível passar à etapa de semi-automação, na qual a coleta e a classificação deverão ainda obedecer aos métodos tradicionais, fazendo-se, no entanto, a indexação e a distribuição sistemática dos dados com o emprêgo do computador. (Gráficos)

Advento da Informática - Quando os elementos colhidos e sistematizados cobrirem tôda ou quase tôda a gama de assuntos que constituem o campo específico de atuação dos órgãos do SIPEC, estará o CENDOC em condições de automatizar inteiramente a sua central de informações. Nessa oportunidade, será possivel operá-la com o máximo de rendimento. Será o advento da Informática no Serviço Público Civil Brasileiro, através de uma aplicação prática no campo da Administração Pública. Vale ressaltar que 



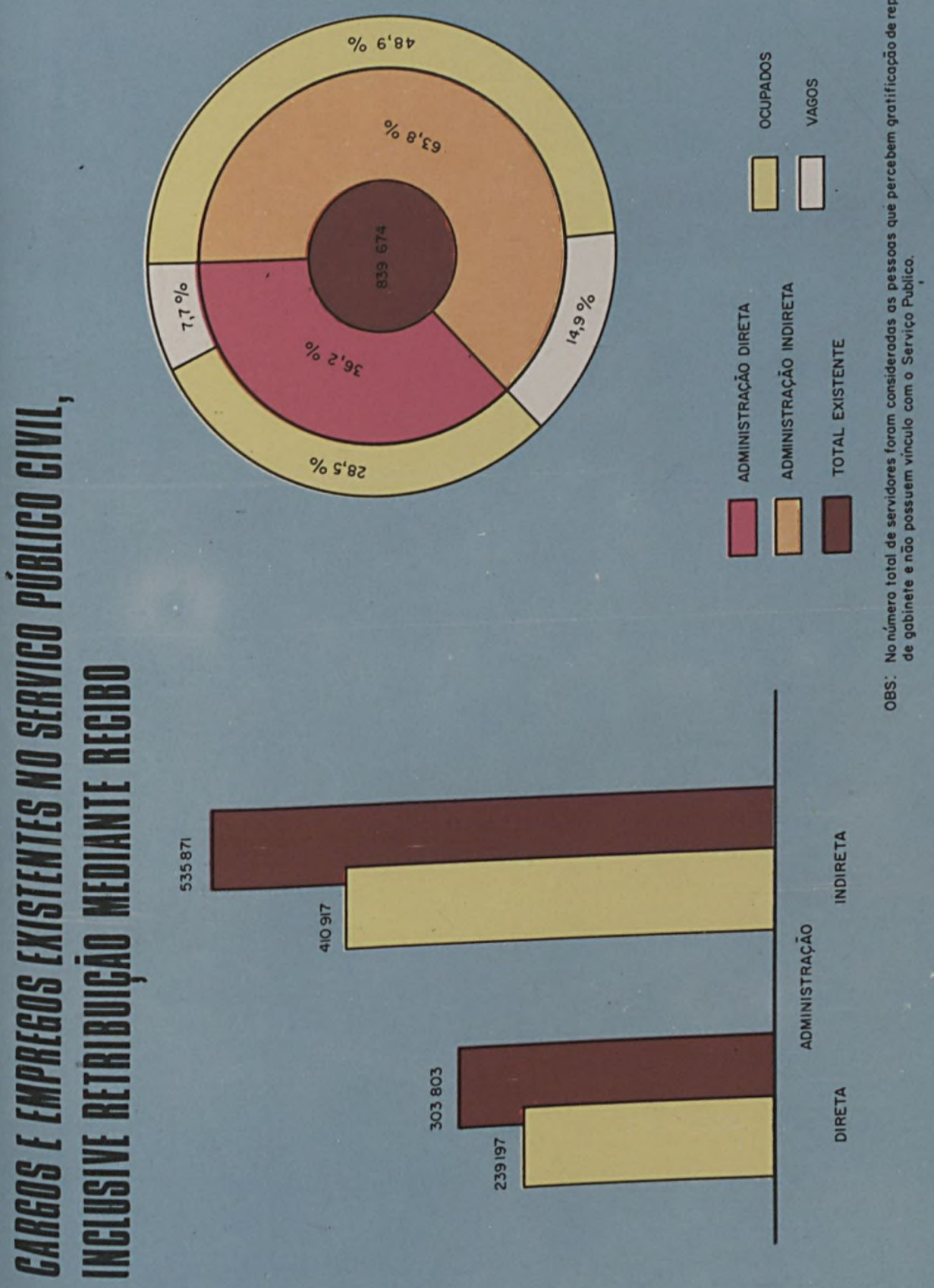





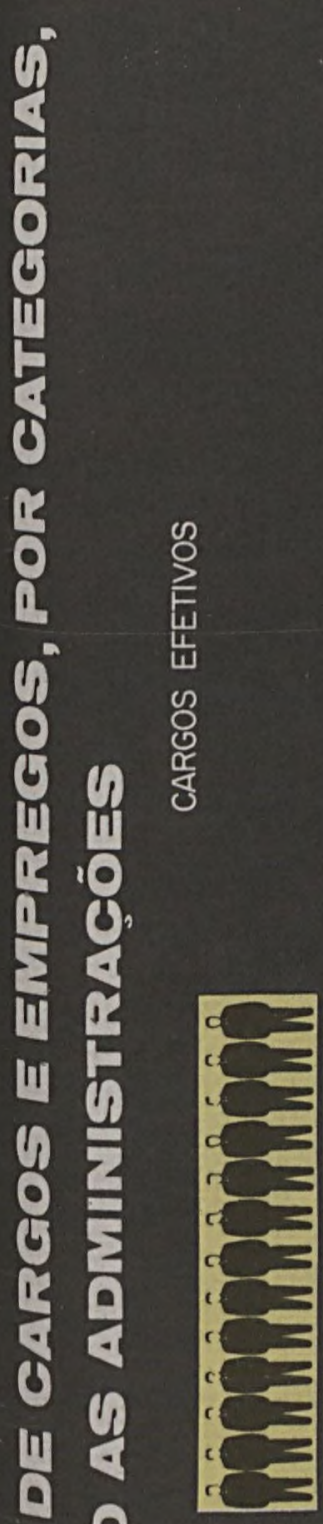

?

-

in

5

3

III

$2 \pi$

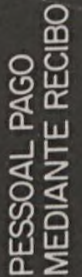

튼

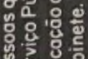

8 o

응응

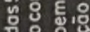

政步

总
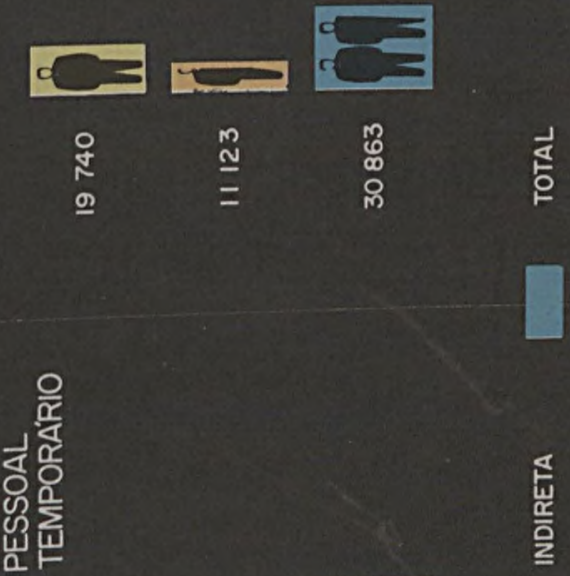

㟒芦

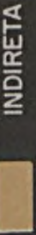

$\frac{\frac{4}{6}}{\frac{0}{0}}$

to

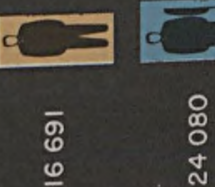

$\frac{0}{\frac{0}{4}}$

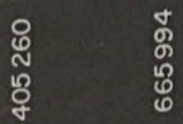

\section{c}

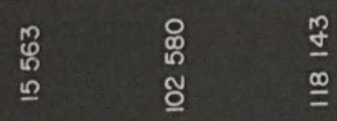





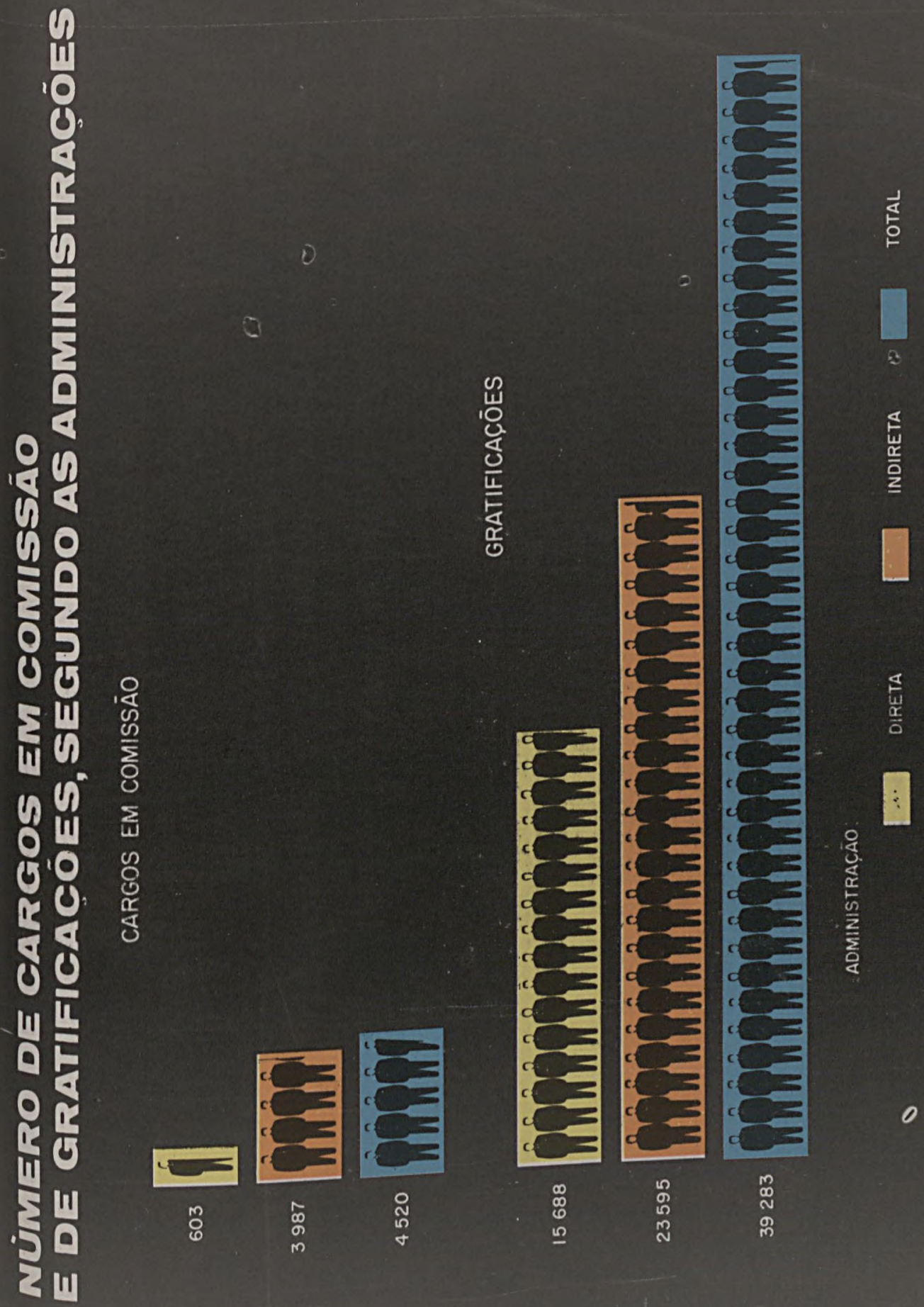





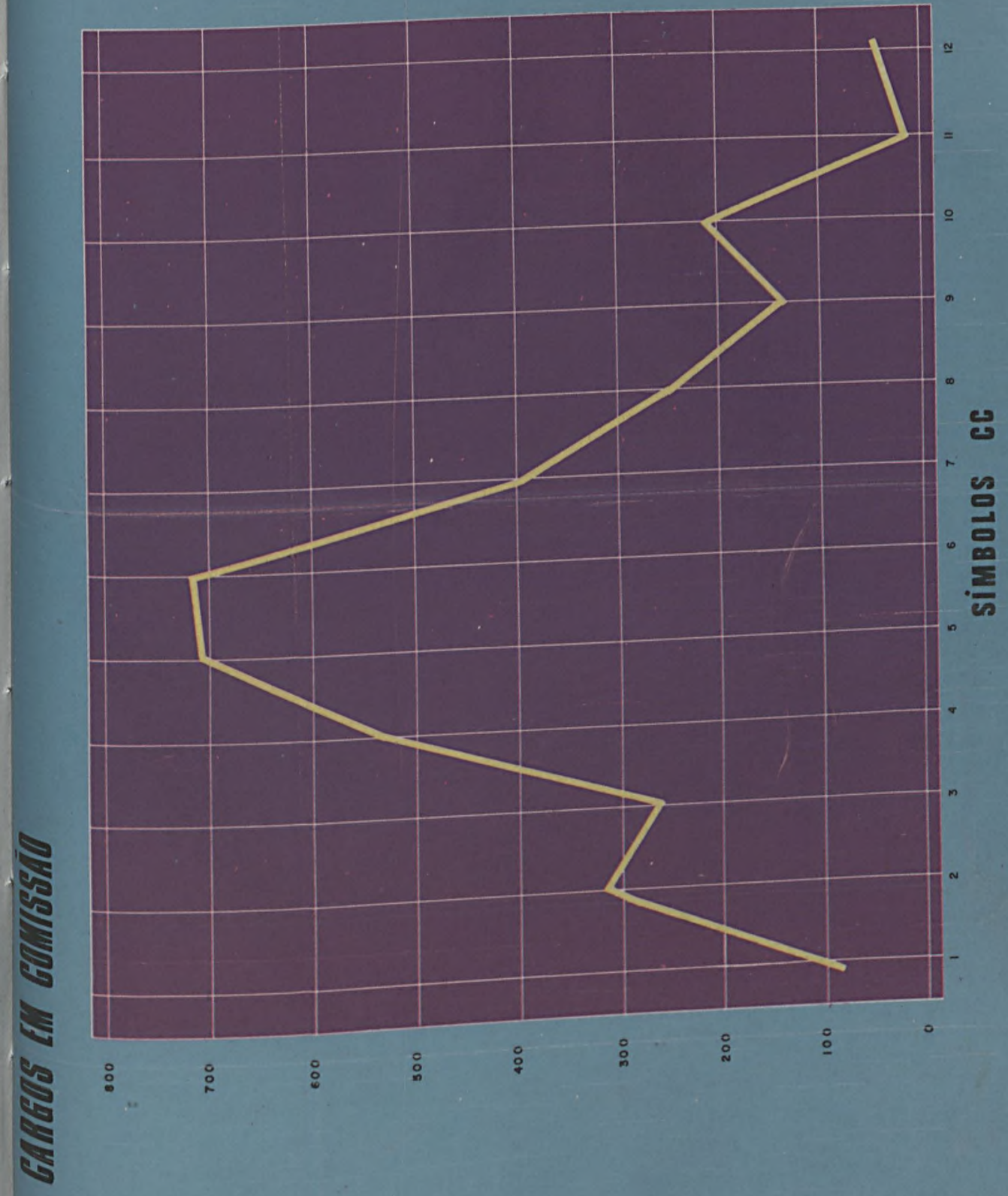





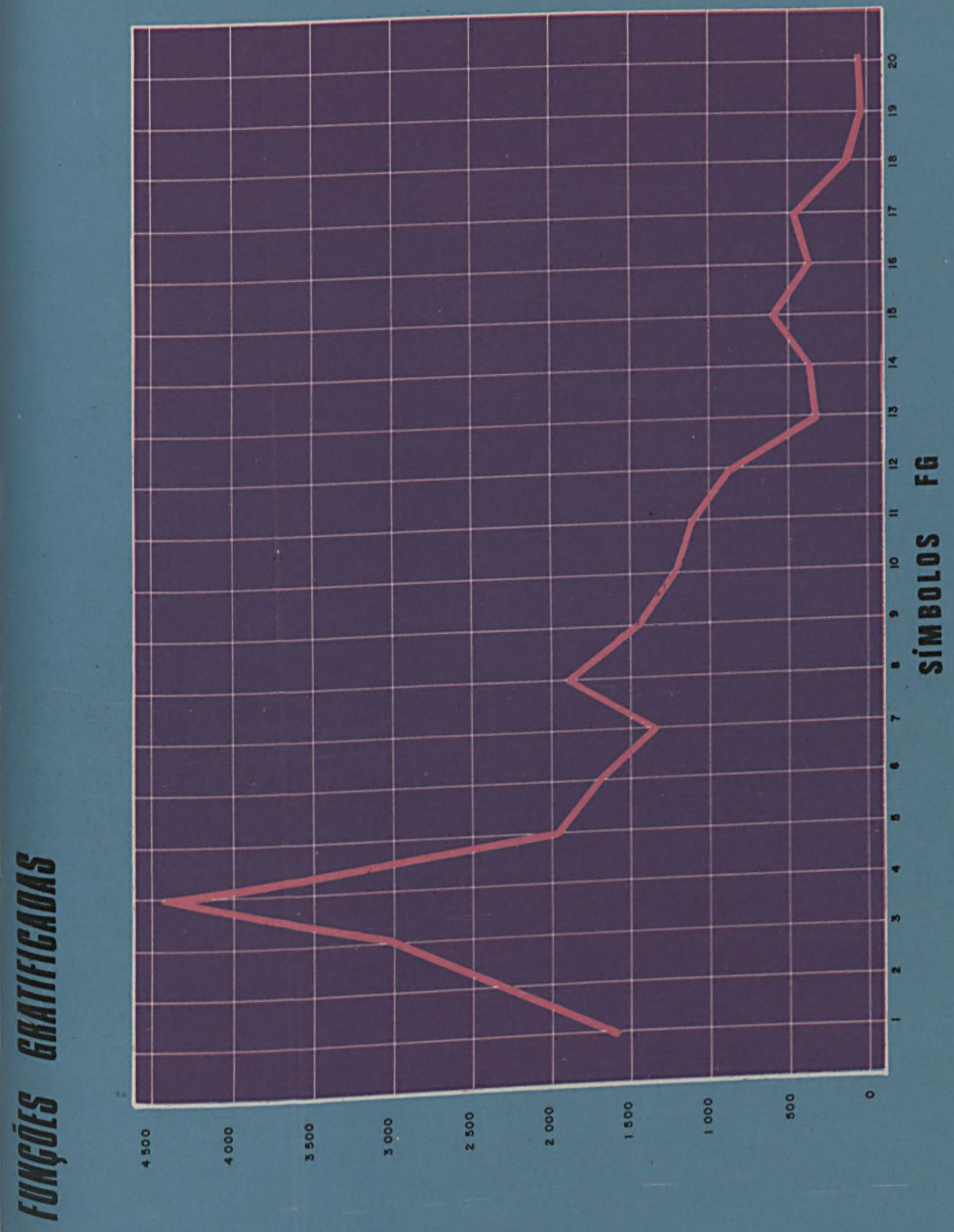





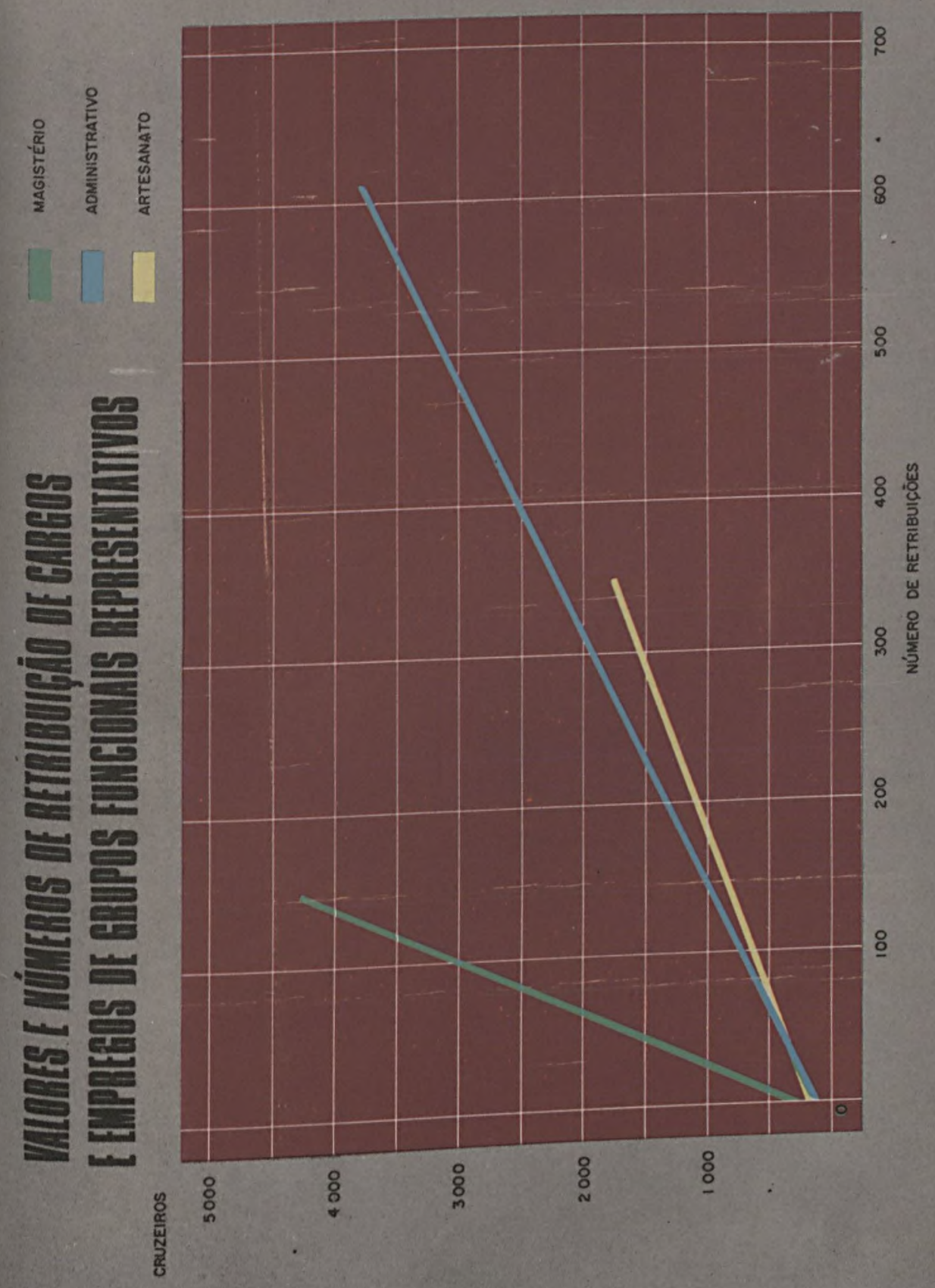





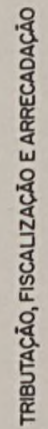
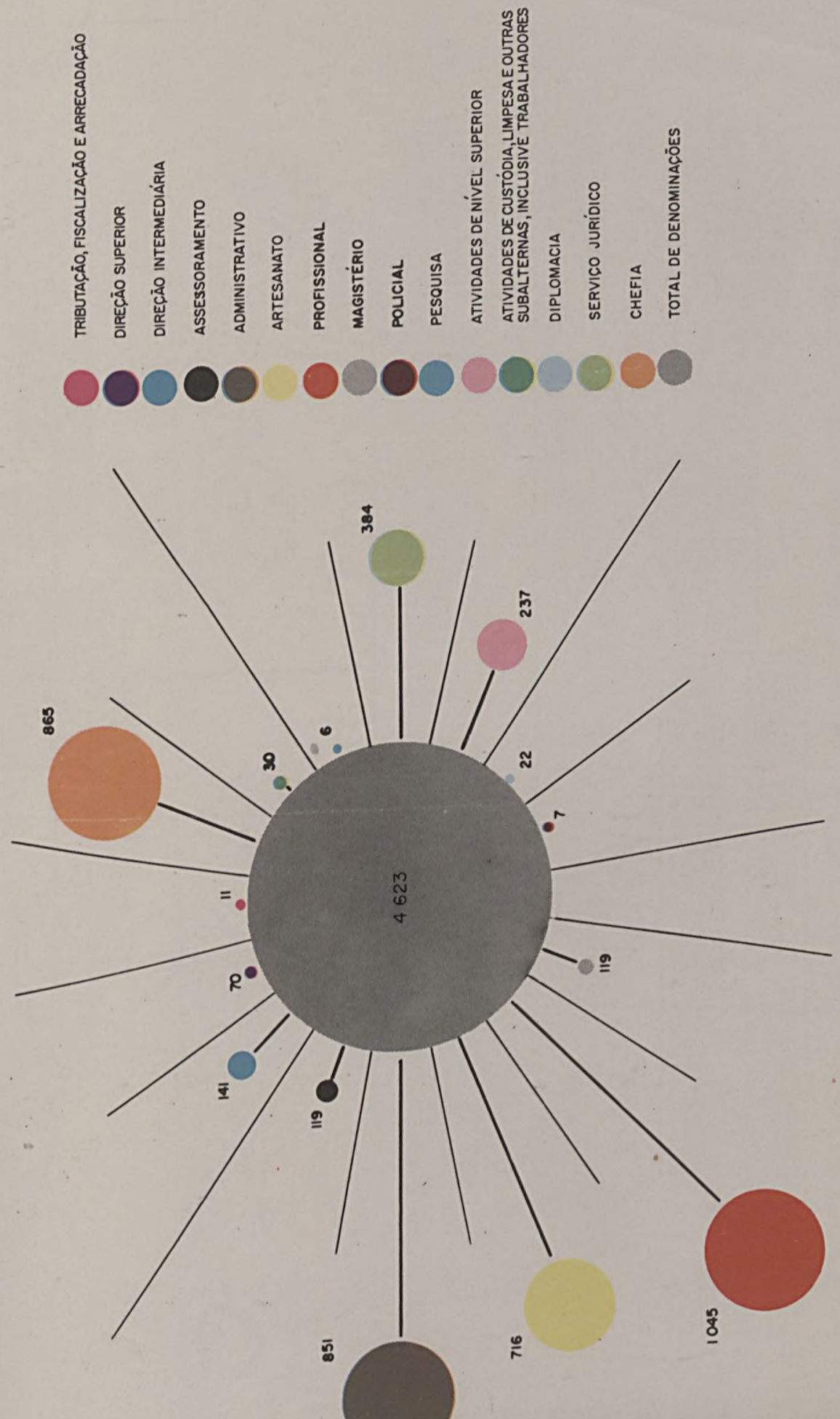



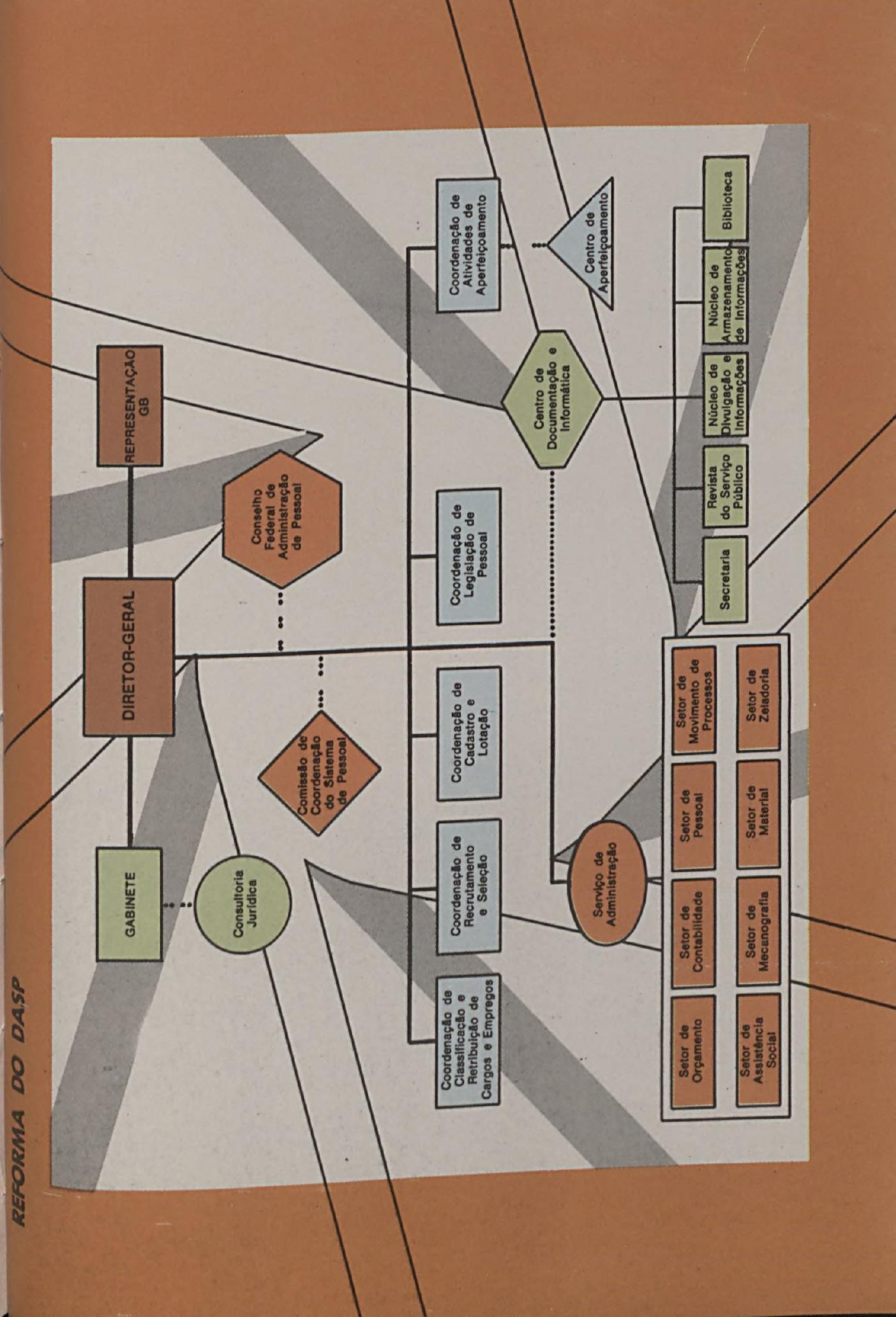

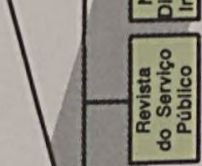





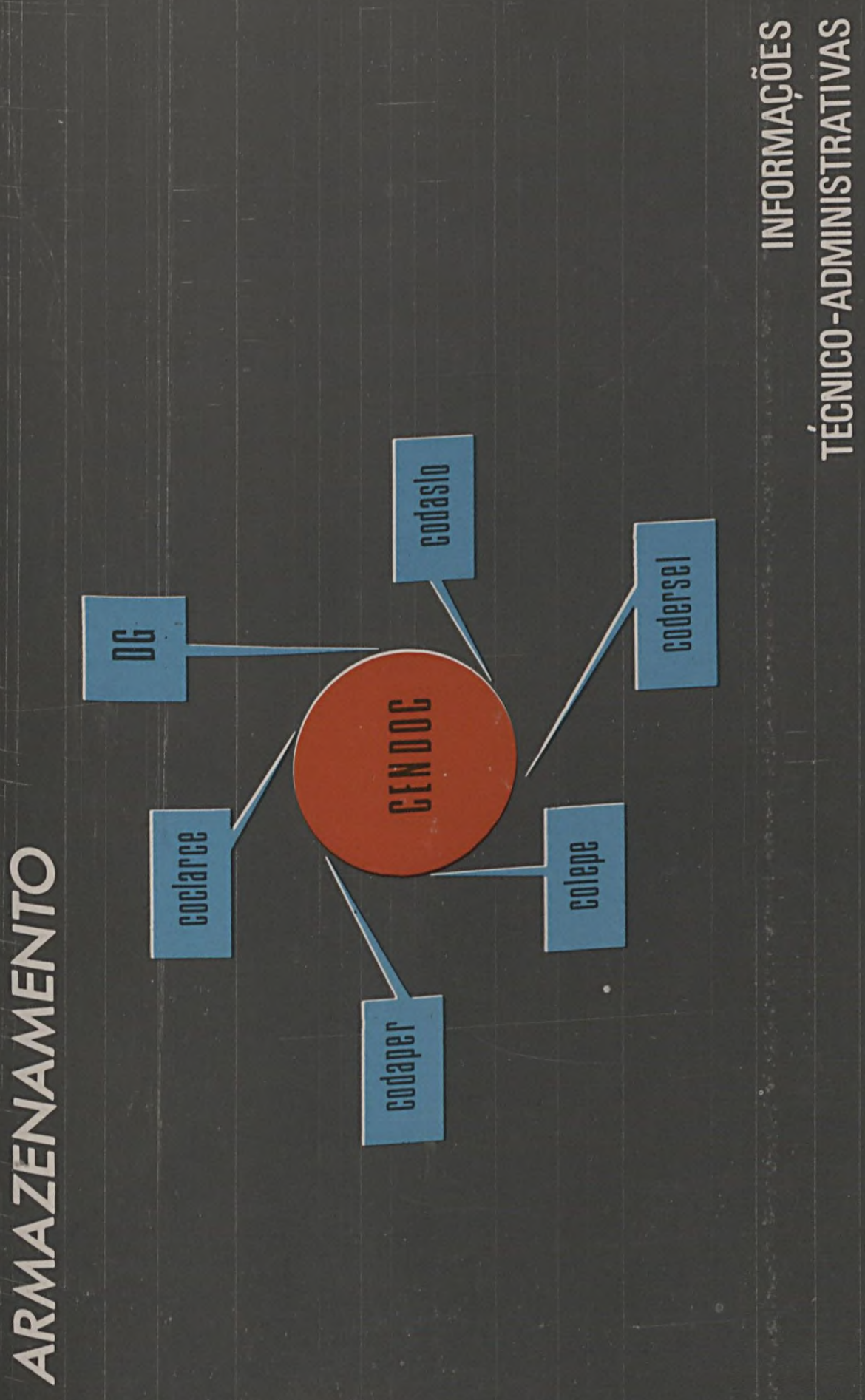






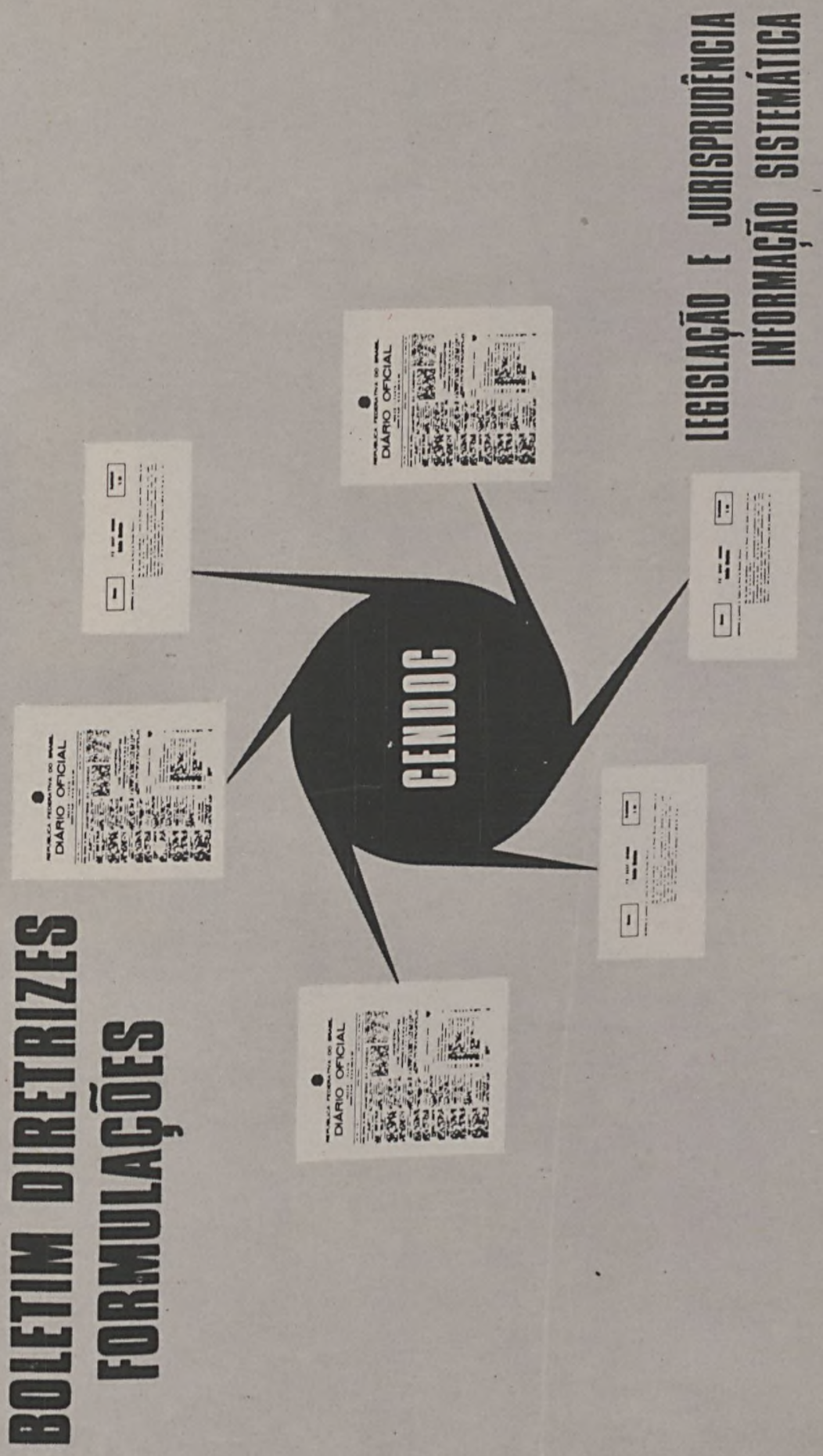


(1)

- $\frac{1}{2}$

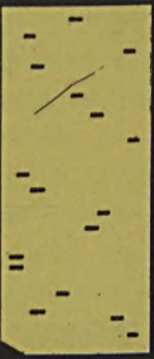

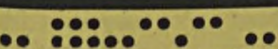
$\because: .: \because: . . . . . .:$ $\because \because \bullet \bullet$

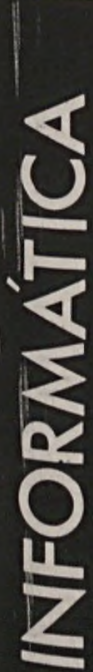

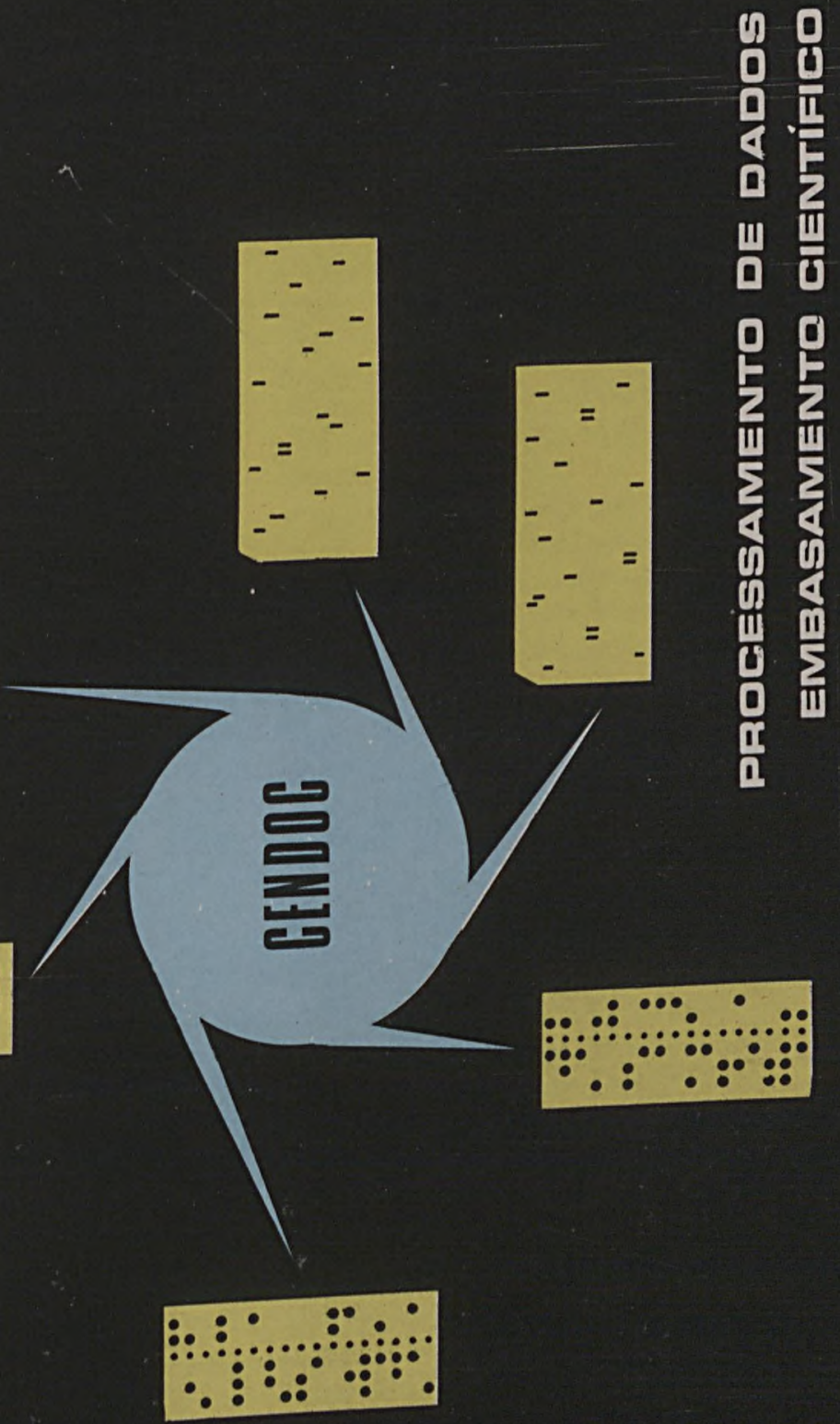



os estudos preliminares encontram-se concluídos, elaborados que foram no decorrer de agôsto a dezembro de 1970. Restará, em última análise, dimensionar, física e financeiramente, a amplitude das alternativas possíveis para o sistema de processamento eletrônico, a fim de que a adoção de uma delas não venha a se constituir num ônus pela subutilização do sistema.

É indispensável e urgente a completa modernização dos processos de armazenagem e divulgação dos dados e informações técnico-administrativas de interêsse para o serviço público, preparando o advento da Informática. $O$ registro integrado e multirrelacionado de dados básicos para o exercício das tarefas de administração dos recursos humanos permitirá aperfeiçoar 0 efetivo funcionamento do SIPEC. Beneficiando-se da implantação dos computadores em suas tarefas específicas, terá o DASP, a longo prazo, condições de instalar e fazer funcionar, completamente, um eficiente sistema de informações que abranja não só a documentação legal, pròpriamente dita, mas sobretudo o oferecimento de uma vasta gama de serviços relacionados com tôda a produção documental ativa do Serviço Público Brasileiro. (Gráfico)

INSTITUCIONALIZAÇÃO DO SISTEMA DE PESSOAL CIVIL DA ADMINISTRAÇAOO FEDERAL - SIPEC

Posteriormente, no conjunto dos diplomas legais sucessivamente expedidos dando substância e forma às metas governamentais nesse campo, sobrevelo o Decreto $n$ \% 67.326 , de 5 de outubro de 1970 , o qual, dando cumprimento aos dispositivos do art. 30 e parágrafos do Decreto-lei n? 200, de
1967, organizou, sob a forma de Sistema, as atividades de Pessoal exercidas pelo Poder Executivo.

Surgiu, assim, no cenário da Administração Pública, o SIPEC (Sistema de Pessoal Civil da Administração $\mathrm{Fe}$ deral), integrando, na sua estrutura, as unidades organizacionais de quaisquer graus especificamente responsáveis pelas atividades de Administração de Pessoal Civil, quer da Administração Direta, quer das Autarquias, tôdas, porém, submetidas à coordenação do órgão Central. (Gráfico)

Reorganizado o DASP e institucionalizado O SIPEC, encontra-se ० Govêrno capacitado para acionar e acelerar a gradual execução das diversas providências básicas já incidentalmente indicadas.

Os gráficos que ilustram esta exposição elucidam os fundamentos, o entrosamento, as peculiaridades e o conteúdo especifico da política de Pessoal em vigor, pelo que nos dispensamos de comentários adicionais.

\section{LOTAÇÃO E AUDITORIA DE PESSOAL. \\ OS PROBLEMAS DA FÔRÇA DE TRABALHO E DA AVALIAÇÃO DO DESEMPENHO}

Embora sucintamente, já foram indicadas as dimensões, finalidades e principais aspectos da reformulação estrutural do DASP, da institucionalização do SIPEC e da organização do Cadastro permanente e atualizado.

Neste tópico, apreciaremos a elaboração e o registro da lotação dos cargos e empregos dos Órgãos da Administração Federal Direta $\theta$ das Autarquias - objeto do Decreto n: 68.991 , de 28 de julho de 1971 , e a implantação da Auditoria nos órgãos integran- 
tes do SIPEC, visando à orientação e contrôle das respectivas atividades específicas, consoante os dispositivos do Decreto $n$ ? 68.992 , de 28 de julho de 1971.

São mecanismos òbviamente imprescindiveis, eminentemente técnicos, que condicionam a normalidade de funcionamento, a eficiência operativa, o contrôle e os resultados da política traçada, cuja execução satisfatória é, certamente, a responsabilidade máxima do Sistema como um todo integrado.

A lotação representa, naturalmente, a fôrça de trabalho, em seus aspectos quantitativo e qualitativo, necessária ao desempenho das atividades normais e próprias das unidades administrativas componentes do conjunto.

$\mathrm{Na}$ conceituação do Decreto que especificamente disciplina a matéria, a lotação tem como finalidade primordial indicar o número de cargos e empregos que, de acôrdo com o respectivo funcionograma, será imprescindivel à unidade administrativa para operar com rapidez.

No estudo e aplicação dos mecanismos da lotação, considerar-se-ão, naturalmente, os aspectos vinculados à situação real e à situação ideal - conceitos essenciais à fixação das medidas positivas de natureza qualitativa - que tem por base a análise das atribuições e funções de cada unidade - e de natureza quantitativa, voltadas para o exame da carga de trabatho existente ou prevista para cada tipo de atribuição ou cargo, em função de projetos e programas de trabalho.

A fim de que alcance os seus verdadeiros objetivos a lotação será fixada: a) em função do atual sistema de classificação de cargos; e b) em função do sistema previsto na Lei número 5.645 , de 1970 .

Quanto à orientação e contrôle dos Órgãos do SIPEC, a serem exercidos sob a forma de Auditoria, o que se pretende é, em síntese, preservar a regularidade das atividades da Administração de Pessoal, a correção de eventuais anomalias, a formulação e diagnósticos precisos, o levantamento de situações ou problemas que exijam perícia especial, a prestação de assistência técnica às unidades administrativas inspecionadas e verificaçăo do cumprimento da legislação especifica.

A implantação da Auditoria, tal como planejada, constitui uma legítima inovação modernizante, destinada, precipuamente, à orientação técnica, à melhoria das condiçöes operacionais de funcionamento dos Órgãos do Sistema e à racionalização dos métodos de trabalho, identificação e formulação - mediante investigação especializada - das providências porventura Imprescindiveis.

A simples leitura do Decreto que dispõe sôbre a Auditoria revela uma concepção atualizada e dinâmica dos processos de contrôle, menos orientada no sentido corretivo do que no da assistência técnica e do incremento dos coeficientes de produtividade.

DIRETRIZES PARA A CLASSIFICAÇÃO DE CARGOS NO SERVIÇO CIVIL DA UNIAO E AUTARQUIAS

Pré-Condições para uma Ação Criativa e Racionalizadora CLASSIFICAÇÃO E AVALIAÇÃO DE CARGOS

Passaremos, agora, ao exame sumário das Diretrizes consubstanciadas na 


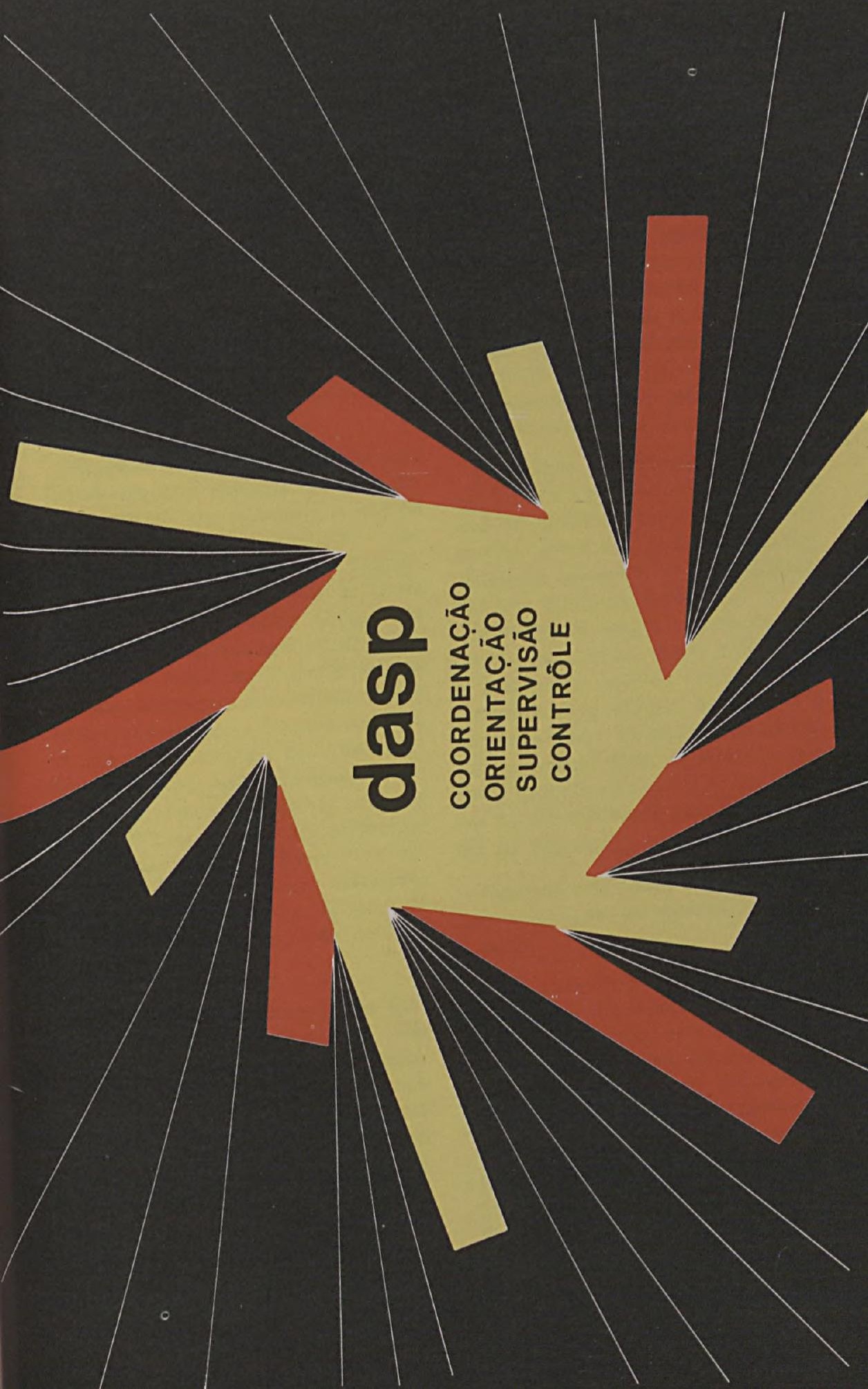



Lei $n$ ? 5.645, de 10 de dezembro de 1970. Êsse é o diploma fundamental que revela $\circ$ propósito do Govêrno a respeito do fascinante tema da classificaçäo de cargos no Serviço Civil da Uniăo e das Autarquias Federais. É o instrumento básico em que se terá de arrimar o nôvo Plano de Classificação de Cargos. Doravante, por uma questão de método, referir-nos-emos a êsse documento apenas como "Lei de Diretrizes".

Estamos convictos de que não será totalmente sem préstimo que nos detenhamos por um momento na análise crítica - rapidissima embora - do "Plano de Classificação de Cargos" aprovado pela Lel $n \div 3.780$, de 12 de julho de 1960. É, como se sabe, o Plano atual, mas que está em extinção. Abrindo o leque de enganos e descautelas técnicas e administrativas que êsse Plano abrigou e fazendo cada um de nós ato de contrição de nossas possíveis faltas por ação ou omissão diante dêsse Plano, estaremos decerto mais bem preparados e equipados para trabalhar num nôvo Plano; num nôvo Plano que represente, realmente, um documento da nossa época; um instrumento de Administração de Pessoal atualizado.

- "Plano de Classificação de Cargos" de 1960 verdadeiramente não chegou a entrar em funcionamento. Não se esperava que êle fôsse uma "ferramenta" perfeita e acabada. Não! Aprendemos, sem recorrer às lições do Conselheiro Acácio, que nada existe assim perfeito e acabado. Tudo quanto fazemos é falivel. E por isso temos de ser inconformados com o que fazemos. Fazer uma coisa dez, vinte vêzes, como procedem os candidatos a viagens espaciais, até encontrar a maneira certa ou, se impossível, a menos errada.

O Plano não tinha um grau de maneabilidade que the permitisse adaptar-se às mudanças por que o mundo passava na década de 60 . Se êle não pôde ter condições de atuação naquela época, imagine-se o que não estaria ocorrendo com um tal Plano na era de tremendo impacto tecnológico que estamos vivendo na década de 70 .

O capítulo da "Readaptação" passou a ser o tema dominante. Um instituto de aplicação excepcional e temporário, como era, visando a corrigir distorções eventuais, só seria adequadamente aplicável depois que se conhecessem os cargos através de descrições minuciosas, exatas e objetivas. $E$ isso nunca ocorreu. Năo mais se respeitavam os campos de atuação $e$ instalou-se uma confusão machadiana: tudo acontecia como na estorinha que nos é contada pelo genial Arthur Koestler no seu fascinante livro "O Fantasma da Máquina".

Façamos uma pausa e vamos relembrar a estorinha de Koestler, que vale a pena.

Certo Marquês da côrte de Luis XV, retornando imprevistamente de uma viagem, encontrou sua espôsa nos braços de um Bispo daqueles heróicos tempos. Depois de um momento de hesitação, o Marquês caminhou ligeiramente para uma janela do prédio e começou a fazer movimentos característicos de quem está abençoando o povo na rua. Aflita e surprêsa, perguntou-lhe a espôsa:

- Que está fazendo você? 
Prontamente the respondeu o Marquês:

- Como o Sr. Bispo está desempenhando minhas funções, eu também posso desempenhar as dêle.

O Plano não tinha o chão em que deve apoiar-se qualquer plano de classificação de cargos: a descrição prévia, clara, simples e objetiva das atribuições, dos deveres e responsabilidades dos cargos. Só se conhece um cargo quando se tem à mão a descrição das atribuições, deveres e responsabilidades que the são inerentes. Se essa descrição prévia inexiste, evidentemente não se conhece nem se pode conhecer um cargo. E se não se conhece um cargo, como se pode classificá-lo? Seria um contra-senso. Mas êsse contra-senso ocorreu, infelizmente. $\mathrm{Na}$ descrição dos cargos, em que se faz, com paciência e seriedade, o minucioso registro de cada ocupação, repousa certamente todo e qualquer sistema de classificação de cargos. E o seu elemento básico, indispensável. É mais do que lógico que uma classificação de cargos não poderá ser meIhor nem pior, em qualquer hipótese, do que a carga informacional coletada, disciplinada e descrita em que ela se irá basear. Se a informação não é fidedigna nem válida, claro está que não será válida nem digna de fé a classificação que nela se fundamentar. Isso é elementar e óbvio. Mas, como bem o afirma o escritor Nelson Rodrigues, "os homens são a tôda hora atropelados pelo óbvio e não o vêem. Só o enxergam quando o óbvio mesmo os agarra pela gola do paletó e grita, de cara fela: - Eu sou o Óbvlol"

Todos sabemos que a determinação prévia das classes, em qualquer plano de classificação, não é matéria intranscendente. É ponto essencial, verdadeira condição de sobrevivência do plano.

Mas o Plano aprovado pela Lei número $3.780 / 60$ foi organizado $\theta$ administrado por espíritos práticos. E os espíritos práticos não padem alcançar a masssa crítica dos problemas. Tinhamos, portanto, de sair dêsse estado de coisas, mas tendo os pés plantados ao chão. Tínhamos de partir para a solução dos problemas que haviam manietado outros administradores e atrasado outros planos governamentais, que dependiam de uma infra-estrutura a administrativa moderna e racional. Efetivamente, não pode haver desenvolvimento em paises que não se lembram de modernizar e dar condições de atuação eficaz à sua administração. A Administração é um dos pilares em que se apóiam os grandes objetivos nacionais.

A questão fol maduramente debatida por técnicos do mais alto gabarito administrativo, tanto do Govêrno quanto da emprêsa privada. $O$ resultado dêsses estudos, o eminente Presidente Emilio Garrastazu Médici aprovou e remeteu ao Congresso Nacional, que o transformou em lei. Essa "Lei de Diretrizes" configura, assim, o primeiro passo realmente positivo para dotar - Serviço Civil Brasileiro de um Plano de Classificação de Cargos eficaz que, por isso mesmo, afina com as exigências múltiplas de um País que está decolando para o desenvolvimento $e$ para a prosperidade.

Essa "Lei de Diretrizes" encerra um conjunto de principios essenciais que, a nosso entender, poderão dar condições de surgimento a um "Nôvo Pla- 
no de Classificação de Cargos" adequado. Por adequado, entendemos um instrumento tècnicamente montado, amparado em orçamentos reais e tranqüilos, e nitidamente administrável.

Vejamos alguns dêsses princípios essenciais:

Plano em aberto - As vantagens que se originam da instituição de um "plano em aberto" são múltiplas e ostensivamente claras. Ninguém tem direito, em principio, de passar simplesmente de uma situação atual para outra situação futura. A transposição ou transformação de cargos ocorrerá, apenas, em consideração às necessidades e conveniências da Administração. Quando êsses cargos estiverem ocupados, isso dependerá de critérios seletivos que irão ser estabelecidos de forma linear e muito objetiva. E, quando isso fôr aconselhável, incluirão, obrigatòriamente, o cumprimento de cursos de reciclagem. Esses critérios seletivos, bem como o treinamento e retreinamento intensivos, estão sendo cautelosamente estudados, para que não fiquemos em terreno opiniático sempre perigoso e estéril. Concordamos totalmente com o ilustre Ministro Delfim Netto, quando diz ficar "irritado diante da impostura da projeção e diante do falso tecnicismo que pretende vender mundos bem arrumadinhos, como se fôssem cigarros dentro do pacote". Portanto, não temos critérios preestabelecidos; estamos estudandoos bem para, quando os definirmos finalmente, aplicá-los com propriedade. A recusa à satisfação dêsses pré-requisitos Importará, para o servidor, em opção pela situaçăo funcional existente e em estágio de extinção, sem prejuizo das promoções $\theta$ acessos que couberem. A possibilidade de passagem para cargo do nôvo Plano é criada pela Administração. Os servidores terão de conquistar, pelo seu esfôrço e pela sua capacidade, o direito a essa transposição. O próprio servidor, sem ficar devendo favores a ninguém, é que deverá demonstrar, objetivamente, o quanto vale e para que cargo valem os seus conhecimentos e a sua experiência. Poder-se-ia quase dizer que êsse princípio do "plano em aberto", pelo substrato de judiciosidade que encerra, é o verdadeiro "princípio da imparcialidade".

Gradualismo - Sòmente os que vivem distanciados da globalidade dos problemas administrativos poderiam supor viável a implantação, por inteiro, do nôvo Plano. A sua implantação será feita gradativamente, em atenção a uma escala de prioridades bem definida. Essas prioridades levarão preponderantemente em conta: 19) a implantação prévia, em cada Ministério ou Autarquia, da Reforma Administrativa, com base no Decreto-lel no 200, de $1967 ; 2$ ?) o estudo qualitativo e quantitativo da lotação de cada um dêsses Órgãos, com vistas a novas estruturas e a novas atribuiçōes que surgirem como decorrência da Reforma Administrativa operada; e 3 ?) a existência, finalmente, de recursos orçamentários para o custeio das despesas geradas. Essa implantação gradualistica configura, como se vê, o elemento fundamental à exeqüibilidade do próprio Plano. É, por assim dizer, o princípio básico de sua sobrevivência. Não fôsse o estabelecimento dêsse principio e o Plano não teria condições de continuidade, já que o Govêrno, empenhado na aceleração do esfôrço para o desenvolvimento, não 
teria a menor possibilidade de financiar-lhe o custeio total a curto prazo. E êste Govêrno, sério e de austeridade indiscutível, não apela para recursos inflacionários, visto como um dos seus objetivos essenciais é a contenção da própria inflaçăo. Os recursos de caixa existentes condicionam a implantação do Plano de Classificação de Cargos. Isso, porém, que em certas circunstâncias poderia representar uma desvantagem ou ser considerado como marcha do caranguejo na luta contra o tempo, significa, em têrmos de realidade, um -princípio do mérito inquestionável. Permitirá, de qualquer forma, a implantação concreta e efetiva do Plano dentro de um período determinado, ao passo que propiciará ao órgão Central de Pessoal a margem de tempo necessária para cuidar, em bases técnicas e altamente realísticas, de que essa implantação se faça cautelosamente e em obediência a critérios absolutamente seguros. É, portanto, um excelente recurso tático dentro da estratégia atinente à programação global do nôvo Plano. Não podemos fugir à intensa atividade executiva do Govêrno, cuja filosofia se encontra no seu Plano Nacional de Desenvolvimento.

Flexibilidade - O futuro Plano terá como base, efetivamente, os pré-requisitos das atribuições, deveres e responsabilidades dos novos cargos. Para a concretização dêsse indispensável embasamento técnico, procederemos à análise meticulosa dos cargos e funções que irão integrar, em têrmos precisos e objetivos, as descrições dêsses mesmos cargos e funçöes. Essas descrições, além de serem ostensivamente importantes na adoção de eficientes sistemas de recrutamento, seleçăo treinamento, ascensão e progressão funcional, permitirão, assim, o conhecimento dos cargos, não só pelos técnicos como por tôda e qualquer pessoa, ensejando uma visão clara e ampla do porquê da classificação de cada cargo. Quando se conhecem realmente os cargos, tem-se possibilidades melhores e mais positivas de trabalhar nêles e com êles. Daí decorre uma flexibilidade operacional altamente desejável para aquêles que vão ter a responsabilidade da administração do Plano de Classificação de Cargo. As descrições de cargos e, portanto, os próprios cargos - como tudo na vida - não são colsas perenes e irreversíveis. $O$ reexame de situações setoriais e mesmo gerais é uma possibilidade que não se pode desconsiderar. Está presente no diaa-dia dos homens que exercem atividades no campo administrativo. Por isso, os administradores do plano não poderiam ter a sua atuação tolhida pela rigidez do instrumento que lhes cumpre aplicar, confrontar, gerir e aprimorar. A rigidez é própria das coisas inanimadas. Do que deixou de ser. Como se mostrou inicialmente, foi a rigidez a concausa que abateu o Plano de Classificação aprovado em 1960. A Lei no 5.645 , de 1970 , só lhe passou 0 atestado de óbito. Todo plano deve ter um grau de maneabilidade suficiente para atender a fatôres novos determinados por qualquer contingência econômica, social ou mesmo técnica. Não pode haver fôrça inovadora ou crlativa em instrumentos rígidos. $O$ homem está pronto a aceitar o desafio das coisas difíceis. Mas não o das coisas emperradas. O plano de 1960 representou, em têrmos reais, uma conspiração total 
contra a flexibilidade. Foi uma lição dura que tivemos de aprender. Mas o ensinamento ficou. O Plano nôvo, por conseguinte, será altamente flexivel e adaptável, no máximo que fôr possivel, às situaçōes de mudança. Está claro, no entanto, que êsse grau de flexibilidade tem de ser bem dosado, a fim de que a flexibilidade que se quer não seja transformada, pelo seu emprêgo distorcido, em "ação desorganizada" na mão de administradores despreparados.

\section{Escalas de niveis sem correspon-} dência obrigatória - Cada Grupo de atividades, ou seja, como exemplos, o de "Pesquisa Cientifica e Tecnológica", o de "Diplomacia", o de "Magistério", o de "Artesanato", qualquer outro previsło na "Lei de Diretrizes" ou que venha a ser estabelecido, terá a escala de níveis de classificação que fôr determinada pela avaliação da importância que tiver para 0 desenvolvimento nacional, bem como pela ponderação especifica das atribuições e responsabilidades funcionais e pelas qualificações exigidas para a execução dessas atividades. Não haverá, portanto, para nenhum efeito, qualquer espécie de vinculação entre os níveis dos diversos Grupos. As escalas serão preestabelecidas pela avaliação simples e objetiva da atividade que estiver sendo considerada, naturalmente em têrmos de relacionamento com as demais, mas sem que haja propósitos de se estabelecer correspondência de níveis. Isso permitirá ao órgăo Central, incumbido da atualização e administraçăo permanentes do nôvo Plano, providenciar a correção na retribuição de um determinado cargo, com vistas a possiveis flutuações ocorrentes no mercado de mão-de-obra,' sem ter de aumentar, necessária e obrigatòriamente, outro cargo de estrutura ou de terminologia aparentada, mas nuclearmente de desempenho menos complexo e de exigência de qualificações de menor grau. Êsse princípio, que mantém estreita coesăo com o princípio da flexibilidade, embora seja mais particularizante, propiciará ao órgão Central do Sistema de Pessoal uma atuação mais consistente no equacionamento das escalas de niveis do futuro Plano.

Redução de cargos - A Lei de Diretrizes prevê, de forma explicita e afirmativa, a redução do número dos futuros cargos. A Administração tem o objetivo de retribuir adequadamente o exercício dos novos cargos. Mas objetiva, também, com isso, obter maior produtividade dos seus ocupantes. Não haverá dispensa de qualquer servidor atual, mas haverá, certamente, o bloqueio ao ingresso nos cargos que surgirão como decorrência do nôvo Plano. O bloqueio a que nos referimos é o estabelecimento indispensável de critérios seletivos muito exigentes, mas lógicos, para o ingresso no nôvo Plano. E quando êsse ingresso ocorrer, no caso de servidor público, ocorrerá concomitantemente a supressão do cargo atual que se vagar. Assim, mantèm-se os cargos atuais com o seu mecanismo de atuação, pecullar, mas não se deixa crescer o número de cargos futuros, nem se permitirá que nêles ingressem elementos não qualificados ou, sequer, medianamente qualificados. A prática dêsse principio não permilirá o crescimento desarrazoado das despesas públicas, já que o propósito do Govêrno, como empregador, é manter quadros funcionais 
estritamente necessários, mas adequadamente remunerados.

Avaliação de cargos - $\mathrm{Na}$ "Leì de Diretrizes" há, também, um princípio multo importante e que configura, para aquêles que vivem na Administração Pública e retribuídos pelos órgãos governamentais, uma regra básica de comportamento. Queremo-nos referir à avaliação de cargos. E quem fala em avaliação de cargos não pode deixar de estar reportando-se, nem mais nem menos, ao equacionamento de uma política salarial apropriada e conforme com as possibilidades do Erário.

Sabemos todos que, no campo salarial, existem distorções que impedem a "criação de um funcionalismo eficiente" como se afirmou nas Metas e Bases para a Ação de Govêrno". Mas essas distorções, criadas ao longo de um passado de que nos estamos tornando livres pouco a pouco, não podem ser suprimidas da noite para 0 dia. Vivemos num Estado de direito e sòmente dentro dêsse contexto é que temos de encontrar as soluçöes para ir corrigindo os desvios salariais.

Temos estudado o assunto, minuciosamente, na área da administração federal e vamos agir com a ponderação que o tema requer, já que não pretendemos saber tudo e a tudo prover. Estamos, sim, detectando fatos, captando anseios, estudando sugestões, levantando estatísticas e analisando possibilidades reais. Como produto direto dêsses estudos, certamente surgirão as conclusões e, com base nelas, as sugestões que se tornarem necessárias. Sòmente dêsse modo será possivel colocar sob contrôle a politica salarial.

É fato certo e inquestionável que a implantação de uma política salarial adequada deve apolar-se no instrumento preliminar e imprescindivel que é a "avaliação de cargos". Essa avaliação, tomadas as medidas cautelares que vimos tomando, elimina em faixa ampla a subjetividade total que existia na fixação de vencimentos, salários ou retribuições. Essa avaliação é o ponto final nos vencimentos atipl$\cos$ e irracionais que todos conhecemos.

E mais do que isso: é um elemento fundamental para o perfeito relacionamento do binômio Administraçăo/ Servidor. Estamos estudando, entre outras atividades decorrentes dos preceltos da "Lei de Diretrizes", os fatôres e subfatôres mais característicos, que venham permitir se processe uma definida diferenciação e hierarquização dos futuros cargos públicos. Se êsses fatôres, como esperamos, se mostrarem sensiveis e, como tais, seletivamente quantificáveis, teremos conseqüentemente salários melhores e mais compativeis com os do mercado de trabalho. Importa ressaltarmos, no entanto, para que não se criem expectativas injustificadas e ilusórias, que tudo isso sòmente se aplicará aos cargos incluídos no nôvo Plano de Classificaçăo de Cargos e com observância completa das disponibilidades orçamentárias existentes. É verdade irrecusável que êsse procedlmento virá melhorar financeiramente os futuros servidores que atenderem aos critérios seletivos estabelecidos. Mas é fato incontestável, igualmente, que protegerá os superiores interêsses do Estado, canalizando para êle servidores com as melhores e mais altas credenciais técnicas e culturais. Os serviços públicos precisam entrar no mercado competitivo de salários para ter 
bons servidores, para sòmente admitir o ingresso nas repartições federais e autárquicas de pessoas em condições de "dar o seu recado". Os serviços do Govêrno também precisam dos grandes talentos. E os grandes talentos custam dinheiro. Mas os dividendos que vêm a render compensam o que se Ihes vier a pagar. Constituem um inegável investimento.

Portanto, o salário adequado, justo, estabelecido mediante uma avaliação de cargos objetiva, simples e racional, sem dúvida facilitará a fixaçăo do servidor competente nos serviços governamentais. E concorrerá, do mesmo passo, para que êle atenda com eficácia plena aos seus deveres e responsabilidades funcionais, como decorrência natural do fato de the permitir que cumpra, financeiramente, com as suas indeclináveis e imediatas obrigações de chefe de família.

Retirando o seu sustento de um só emprêgo ou atividade que the assegure uma existência tranqüila e estável, nenhum homem, de maneira geral, corre em busca de outras fontes de renda adicionais. Integra-se numa posição e dá de si o máximo que pode, adquirindo, a par disso, uma consciência profissional reta e produtiva. E a formação dessa consciência profissional no servidor público é a meta básica da política de pessoal dos órgãos governamentais.

A classificação e a avaliação de cargos são intrumentos técnicos que independem um do outro, mas que sòmente são eficazes quando aplicados conjuntamente.

Continuidade - O nôvo Plano de Classificação de Cargos, em consonância com o comando advindo da
"Lei de Diretrizes", será administrado pelo Órgão Central do Sistema de Pessoal. Múltiplas são as vantagens decorrentes dessa medida. $O$ instrumento terá uma integração técnica harmoniosa em que será dada cabal atenção aos princípios que o inspiram e que 0 irão nortear. Fica-Ihe afastada, igualmente, a manipulação amadorística ou de elementos tècnicamente desqualificados. Os aspectos dinâmicos da administração do Plano se beneficiarão, assim, enormemente dessa administração equilibrada, equânime, corretiva, aperfeiçoadora e atualizante. 0 reajustamento constante do Plano às realidades do momento não permitirá que êle sofra interrupções ou colapsos indesejáveis. Essa realimentação permanente, que configura 0 princípio da continuidade, é a própria alma do Plano. Sem êsse elemento ativo e consciente da importância de um Plano de Classificação de Cargos, êste não passaria de uma simples receita. O Plano, sòmente como receita, é coisa anti e ante-revolucionária. Queremos um instrumento que nos permita atuar em têrmos concretos. O nôvo Plano terá, portanto, uma administração moderna e dinâmica a cargo de um DASP renovado estruturalmente e com o grau de maturidade necessária à compreensão dos tempos novos.

A "Lei de Diretrizes" encerra, ain$\mathrm{da}$, outros principios essenciais, tais como os de "mérito abrangente", "treinamento intensivo", "descentralização operativa" e "funcionamento sistêmico". Esses princípios, embora muito importantes também, não configuram, entretanto, "aspectos novos". Estarăo presentes, no nôvo Plano, como elemento de comparecimento indispensável $\theta$ observância irrestrita. 
Há, todavia, algumas disposições da "Lei de Diretrizes" que nos exigirão observações ligeiras. E isso é realmente impositivo, uma vez que se acham inseridas, expressamente, na nossa temática. Queremo-nos referir à progressão e ascensão funcionais.

A promoção é o antepassado, em extinção, da progressão prevista na "Lei de Diretrizes". Estamos com a responsabilidade de coordenar a execução de um nôvo Plano de Classificação. E estamos plenamente cientes dos erros e das ingenuidades anteriormente cometidos. Esforçamo-nos por estudar e perquirir todos os aspectos dos problemas de Pessoal. Pretendemos dar ao nôvo instituto uma funcionalidade que 0 agilize e vitalize. Precisamos, portanto, encontrar o caminho certo para desenredá-lo da processualistica exasperantemente morosa, que o tem atado e manietado. Não nos preocupamos com o problema da progressão funcional, em si mesmo, e sim com a sua solução. Perseguimos, neste particular, um desfecho simples e linear. Mas que seja entendido por todos e aplicado por todos os que tiverem a responsabilidade de aplicá-lo. Aceitaremos tôda e qualquer sugestão para estudo. A promoção, como já dissemos antes, é entendida por nós como o antepassado da progressão. E assim o entendemos, porque a palavra antepassado significa o que passou antes. A promoção para nós realmente passou. A progressão virá para ficar, para caminhar para diante. A carga semântica da progressão inscrita na "Lel de Diretrizes" não se confunde; por conseguinte, com a que se continha ou se contém na da promoção existente. Esta configura um quietismo e uma inércia incompatíveis com a ação e dinamismo que pelejaremos por imprimir àquela. E estejam certos os servidores públicos de que, com a ajuda de todos, teremos uma "progressão funcional" viva, atuante, visto que ela é a pré-condição impositiva de uma Administração de Pessoal criativa $e$ racionalizadora.

No que respeita à ascensão funcional, $\theta$ evidente que nos seus objetivos ela participa da natureza do que o plano aprovado pela Lei $n$ ? 3.780 , de 1960, chamou de acesso. É um instituto complementar da progressão funcional. Embora o acesso tenha atraído em menor escala a simpatia dos que consideram como atividade-fim da $\mathrm{Ad-}$ ministração de Pessoal as explanações legais e os tecnicismos processualisticos, não se pode negar que, também êle, caiu num irritante compasso de espera no campo de aplicação prática. Tais síncopes fizeram-no perder fôrça e substância, com evidentes prejuizos para a própria Administração. Pascal afirmava que é próprio do homem progredir. Entre um caminho de progresso difícil, complicado e parcimoniosamente retribuido, e outro livre de empecilhos e bem remunerado, ninguém escolherá o primeiro. A ascensão funcional está, também, sendo dissecada. Pretendemos, ao fim da tarefa a que estamos imprimindo a maior velocidade, que o nôvo instituto tenha uma aplicabilidade prática adequada.

Um Plano de Classificação de Cargos é trabalho de fôlego. Queremos todos que o nôvo Plano seja um documento avançado, mas realista e compativel com a empolgante era em que vivemos.

Estamos caminhando seguramente em direção a objetivos reais, palpá- 
veis e possiveis - e não ao encontro de miragens, sonhos ou ilusões.

\section{RECRUTAMENTO E SELEÇÃO}

Instrumento significativo do sistema do mérito, o exercício das atividades de recrutar e selecionar fol - e continua sendo no Brasil - uma preocupação permanente, cuja importância vem crescendo de vulto à medida que os órgãos da Administração expandem suas atividades e aprimoram os respectivos serviços. Neste sentido, a institucionalização do processo seletivo, abrangendo, inclusive, as adminissões de empregados, vem-se impondo progressivamente como um avanço inegável.

Quanto aos métodos, observa-se que, ao longo dêsse tempo, prevaleceu o aferimento apenas do nivel intelectual ou de instrução dos candidatos, mediante a submissão dêstes às tradicionais "provas de conhecimento".

Aliás, em recente relatório, o GrupoTarefa criado na Coordenação de Recrutamento e Seleção, como marco inicial para a implantação de nova metodologia nesse campo, formulou um diagnóstico objetivo da situação, isto $e$ e, identificou os aspectos legais, efetuou pesquisa de campo sôbre o problema $e$ as possibilidades de utilizar técnicas psicológicas na aplicação do recrutamento e seleção para, afinal, formular as diretrizes a serem propostas.

As sugestões formuladas no tocante à implantação do Recrutamento dirigido objetivam, em linhas gerais:

a) informar, divulgar e explicar, de modo uniforme e padronizado, os sistemas de classificação e retribuição de cargos, empregos e funções pelas atri- buições, tarefas típicas, qualificações, peculiaridades, salários e vantagens.

b) integrar a rêde de educação pública e particular, bem como as instituições de treinamento e aperfeiçoamento no uso contínuo de especificações padronizadas, pelo ajustamento do conteúdo de seus cursos às exigências típicas do grupo de cargos e empregos;

c) criar uma consciência de direitos e deveres, nos seus aspectos morais e cívicos, junto à juventude brasileira, durante os anos de sua formação;

d) envolver emprêsas educacionais, psicológicas, jornalísticas, de rádio, televisão e cinema, nessa divulgação padronizada do sistema de classificação de cargos, funções e empregos.

Quanto à seleção, julgou aquêle Grupo mais oportuno que, em vez de norma única, melhor seria introduzir a seleção psicológica com norma bácisa e com várias alternativas quanto ao seu "modus faciendi":

a) solicitação de laudo psicológico de clínica credenciada, para cargos e funções de nivel superior;

b) execução das provas psicológicas por instituições credenciadas;

c) realização de exames pslcológicos, por parte dos órgãos, depois das provas de conhecimento;

d) seleção positiva, assim entendida a realização em duas fases, isto é, exames psicológicos como primeira etapa do processo seletivo e, a seguir, estágio-desempenho, instrumento destinado a aferir rendimento do candidato em serviço.

Em sintese, depois das pesquisas realizadas e obtenção do pleno conhecimento cientifico dos problemas des- 
sa área vital para a Administraçăo de Pessoal, examina-se a adoção:

a) de nova metodologia de Recrutamento e Seleção, com as respectivas normas;

b) do Estágio-Desempenho, com tôda a rotina detalhada;

c) do sistema de credenciamento para prestação de serviços técnicos;

d) de nova sistemática quanto ao prazo de validade de concurso, à babilitação de candidatos e à criação de estoques médios de candidatos;

e) de nôvo sistema de inscrição que permita uma análise sócio-econômica dos candidatos;

f) do sistema de treinamento de agentes setoriais, por meio de instrução programada, questionários dirigidos e participaçăo crescente;

g) de calendário de concursos, como um dos instrumentos de programação e disciplinamento de política de pessoal.

Esses critérios serão, naturalmente, compatibilizados com a realidade regional e estabelecidos em coerência com as dificuldades decorrentes do mercado de trabalho local e as características próprias de cada unidade administrativa interessada.

Conseqüentemente, para todos os cargos e empregos os processos seletivos promoverão a escolha de candidatos que, tendo preenchido os requisitos mínimos estabelecidos, revelem favoráveis condições de desenvolvimento no Serviço Público.

\section{MÉRITO E TREINAMENTO ABRANGENTES}

A moderna administração tem por objetivo promover a elevação do ren- dimento da mão-de-obra. $\mathrm{Na}$ verdade, visa à melhoria da produção, quer de bens, quer de serviços, partindo, inicialmente, da avaliação quantitativa e qualitativa do pessoal requerido para cumprimento dos programas de trabalho.

Diante dêsse enfoque - e considerando que o treinamento é um autêntico investimento - a preocupação governamental com a atividade de trelnamento no Serviço Público tomou novos rumos, mormente em têrmos de sistema no qual a tônica passará a recair no adestramento contínuo em todos os niveis e em todos os setores.

O propósito é o da compatibilização de mão-de-obra com os modernos métodos, técnicas e equipamentos e sua harmonização com a política $\theta$ os programas de govêrno visando à valorização e dignificação do servidor público, à constituição de quadros dirigentes mediante formação $e$ aperfeiçoamento de administradores capacltados, à retribuição baseada na avaliação das funções a desempenhar.

Tôda essa formulação recai sôbre o Órgăo Central do Sistema, incumbido de orientar e coordenar a Administração de Pessoal Civil, tendo em vista o cumprimento de novas Diretrizes nesse campo. Para isso, deverá dispor de uma rêde de entidades integradas no Subsistema de Aperfeiçoamento.

Cuida-se, agora, de uma programação básica global com execução descentralizada por Ministérios e Autarquias. O objetivo é permitir o pleno aproveitamento do potencial humano sủscetível de adestrar-se em função das necessidades setorials, sem que se perca de vista a orientação central do Govêrno. 
Para êsse efeito, está em funcionamento no DASP um grupo de trabaIho constituído de especialistas em treinamento e análise de sistema que proporá, sob a forma de perfis, normas a serem adotadas por todo o Subsistema, partindo de matrizes elaboradas, das quais resultarão programas, curriculos e métodos didáticos de larga aplicação.

Além disso, ocorrerá o entrosamento cada vez mais intimo entre o treinamento, de um lado, e o recrutamento e a seleçăo, de outro, pois as autoridades empenhadas na direção do segundo setor têm grande parcela de responsabilidade nos processos do primeiro.

o trabalho, em suas linhas gerais, pode encontrar expressão nos seguintes tópicos:

a) anteprojetos de normas gerais de treinamento;

b) plano de treinamento avançado para pessoal destinado à direção $e$ assessoramento superiores;

d) planos básicos de cursos de aprendizagem e de especializaçăo para pessoal de carreiras burocráticas;

e) planos básicos para cursos de orientaçăo, de adaptação, supletivos e de extensão em linhas profissionais;

f) diagnósticos analíticos e continuados do sistema de aperfeiçoamento no Serviço Público;

g) estudos dos métodos de coordenação de recursos didáticos e programáticos;

h) planos de avaliação de necessidades de treinamento e elaboração de projetos alternativos de aproveltamen- to direto da mão-de-obra qualificada no processo;

i) estabelecimento de créditos para escolha de métodos didáticos para as várias clientelas das unidades de treinamento;

j) programação de cursos básicos para fins seletivos;

I) estudos sôbre utilização de recursos técnicos e sôbre viabilidade $\theta$ oportunidades da cooperação das organizações externas no treinamento;

m) programação de adestramento com projeção de alternativas quanto ao emprêgo de técnicas de laboratório, de casos, de dramatização, de situaçőes simuladas etc.

Direção e Assessoramento Superiores - No elenco das indicaçöes contidas no documento que instrul a Reforma Administrativa Brasileira, um dos tópicos básicos é o referente à Direção e Assessoramento Superiores.

Relevante é o recrutamento, a seleção e o preparo não só de pessoal para êsse escalão, como, também, dos elementos que se destinam às chefias e às funçōes técnico-especializadas, tarefas a cargo do Centro de Aperfeiçoamento, órgão autônomo vinculado ao DASP.

Isto importa em conceituá-lo como órgão de altos estudos administrativos, ao qual compete promover a capacitação profissional para êsse nivel, com vistas à constituição de uma reserva de onde serão captados os recursos humanos necessários ao preenchimento dos altos postos que compõem a supra-estrutura administrativa dos Ministérios e Autarquias. 
Em síntese, o referido Centro é de excepcional importância para o Serviço Público Civil. O treinamento está vinculado à necessidade de, afastando o amadorismo e a improvisação, abastecer o Govêrno de assessôres e dirigentes, adequadamente preparados.

$O$ atual enfoque pode sintetizar-se nos seguintes tópicos:

a) concluídos os estudos relativos ao desenvolvimento do Subsistema de Treinamento e à estrutura e programação do Centro de Aperfeiçoamento, diligenciar a provisão dos insumos requeridos;

b) recrutar, em função das diretrizes gerais do Govêrno, pessoal de nível universitário a ser selecionado para os cursos avançados de Direção e Assessoramento Superiores da Administração Civil;

c) iniciar a execução do programa de treinamento do pessoal selecionado segundo as normas diático-pedagógicas prèviamente estabelecidas;

d) avaliar a aprendizagem segundo métodos modernos, tendo em vista apurar o aproveitamento do treinando em tôdas as matérias do currículo, bem como o respectivo comportamento.

Finalizando, é mister ressaltar que consta do projeto, já em estudos, de viabilidade, a construção, em Brasilia, da sede do Centro de Aperfeiçoamento como instituto de ensino e pesquisa de administração pública.

EQUIPES TÉCNICAS DE ALTO NIVEL

A Lei $n$ ? 5.645, de 1970, previu, com a finalidade de assegurar a uniformidade de orientação dos trabalhos de elaboração e execução do Plano de Clas- sificação de Cargos, a constituição e o funcionamento das Equipes Técnicas de alto nivel no âmbito de cada Ministério, Órgão integrante da Presidência da República, ou Autarquia, e sob a presidência do dirigente do Órgão de Pessoal respectivo, com incumbências especificas a serem exercidas em permanente e estreita articulação com o DASP, que orientará e coordenará as atividades levadas a efeito em regime descentralizado.

Constituem atribuições essenciais das Equipes Técnicas determinar quais os Grupos de Categorias Funcionals que devam ser abrangidos pela escala de prioridades que orientará a gradativa implantação do Plano de Classificação de Cargos, além da orientação e supervisão, nas respectivas áreas, dos levantamentos e análises imprescindiveis aos trabalhos relativos à sua elaboração e execução.

A descentralização dêsses encargos proporciona aos órgãos de Pessoal em contato direto com os fatos, a oportunidade de, analisadas as necessidades setoriais, propor as soluçőes que melhor atendam aos interêsses da própria Administração.

São encargos prioritários que, simultâneamente com outras medidas igualmente importantes, contribuirăo para a realização de um Plano à altura das exigências técnicas da moderna Administração de Pessoal.

Metodologia de Implantação dos Novos Planos de Classificaçăo de Cargos e de Retribuição - A implantação gradativa dos novos planos compreenderá três etapas distintas, cada uma delas com a adoção de metodologia específica. 


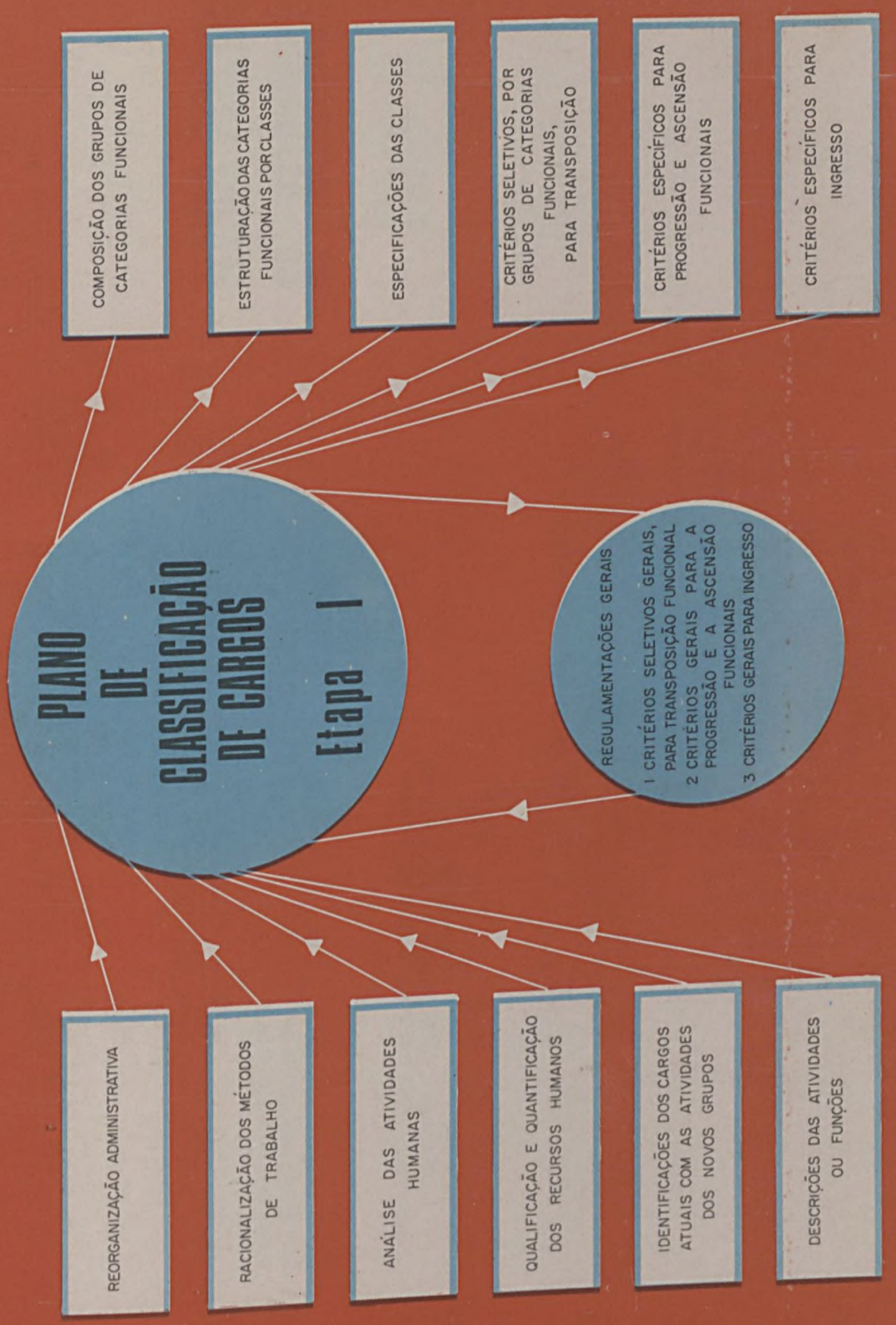





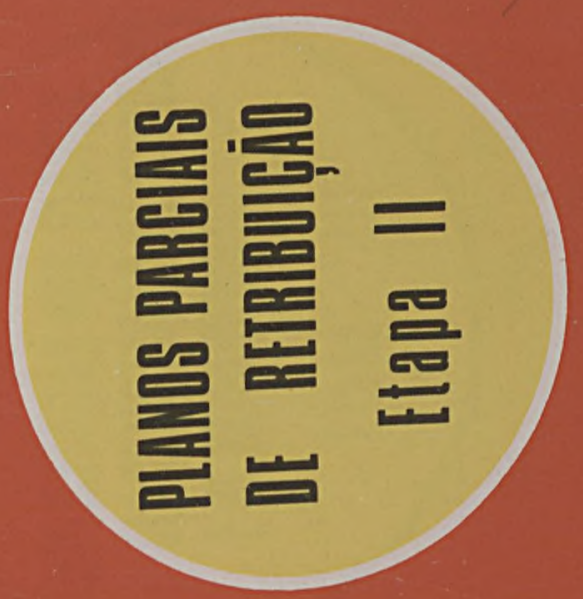

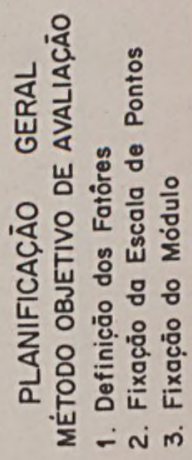

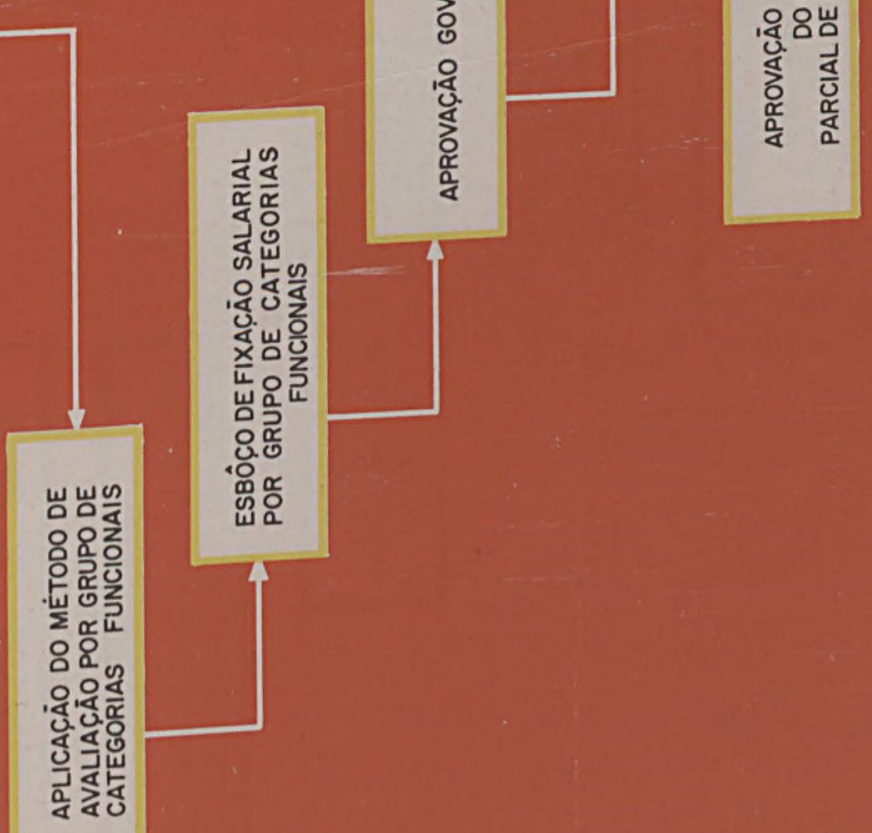





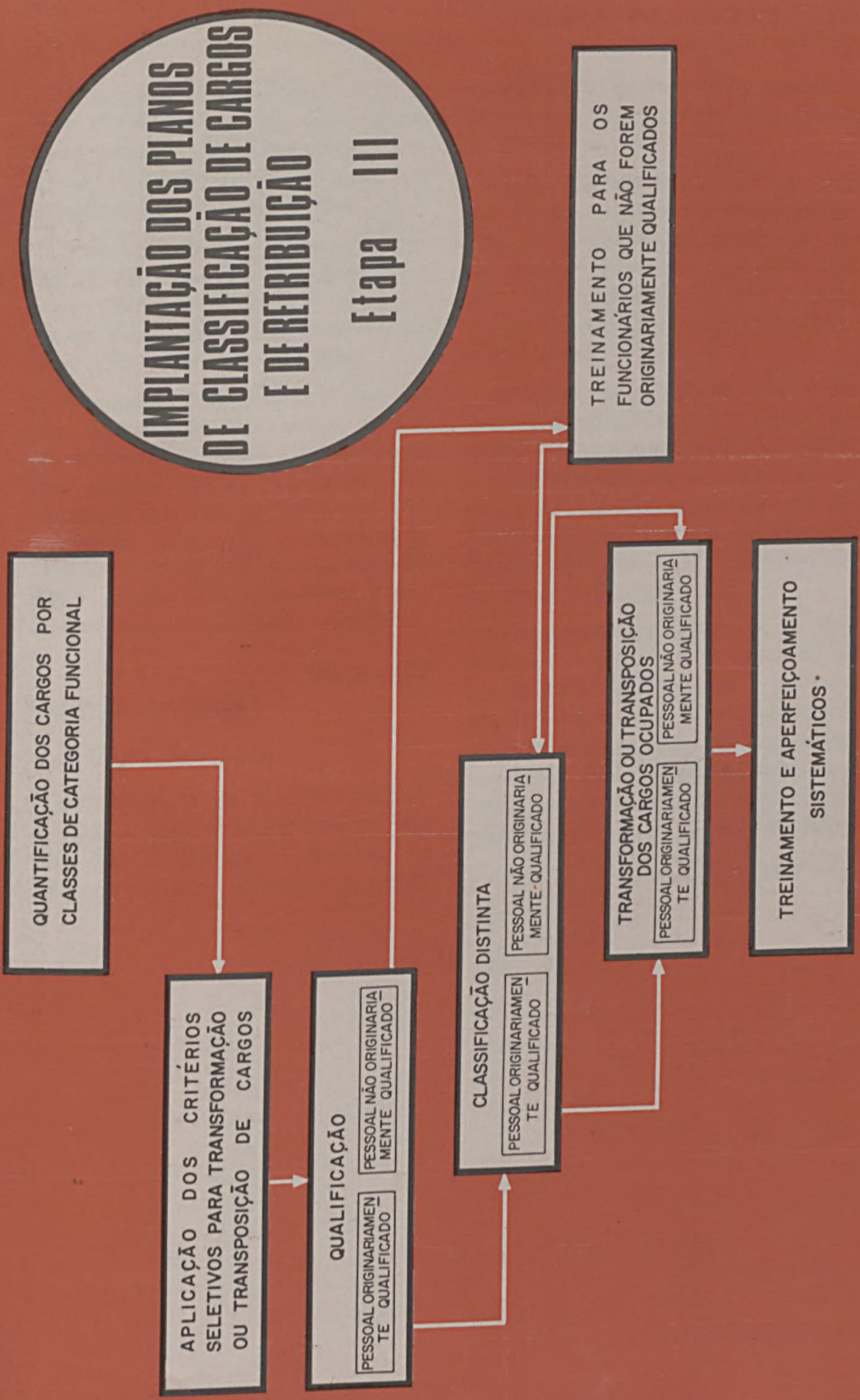



A primeira etapa abrange duas fases diferenciadas: uma, de medidas preliminares e imprescindiveis à montagem do Plano de Classificação, que constitui a outra fase. (Gráfico)

A segunda etapa se refere à elaboração do Plano de Retribuição de cada Grupo de Categorias Funcionais, desde os estudos preliminares até sua aprovação legislativa. (Gráfico)

A terceira etapa alcança a dinâmica de implantação dos novos planos, compreendendo desde a quantificação dos cargos virtuais, passando pela aplicação dos critérios seletivos e conseqüentes qualificação e transposição dos funcionários para a nova situação, até a adoção Institucionalizada e programática do treinamento. (Gráfico)

\section{Senhor Presidente}

Senhores Deputados:

$\mathrm{Na}$ convicção de havermos proporcionado a Vossas Excelências, em síntese clara e objetiva, o panorama da Açăo do Govêrno no campo da Admi- nistração de Pessoal Civil, agradecemos a generosa atenção e o fidalgo acolhimento.

Seria temerário supor que nos limites de uma ligeira exposição pudessem ser esgotados os problemas que se compreendem nessa área de Govêrno e Administração sumamente vasta, complexa e de abordagem indiscutivelmente difícil.

Acreditamos, no entanto, que os dados fundamentais e os conceitos básicos do tema bastam para caracterizar a magnitude das responsabilidades que temos de enfrentar na direção do órgão Central do Sistema de Pessoal, sempre sintonizado com as diretrizes do Govêrno da Revolução.

Temos a certeza de que, com a derrocada dos preconceitos tradicionais, dos anacronismos teóricos e práticos, das dificuldades e incompreensões que obstaculizam a atuação dos Administradores, estamos realizando uma obra identificada com as aspirações e interêsses superiores da Nação Brasileira.

Muito obrigado. 


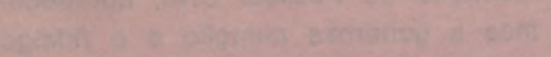

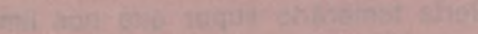

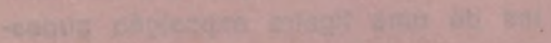

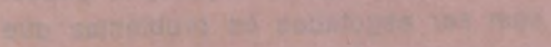

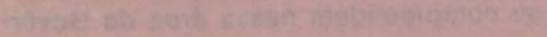

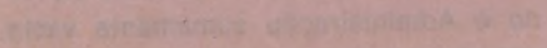

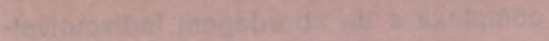

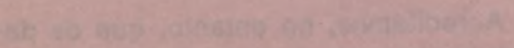

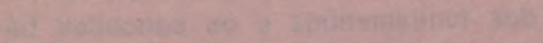

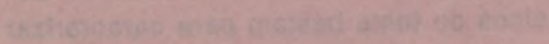

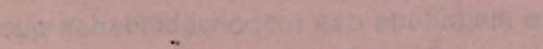

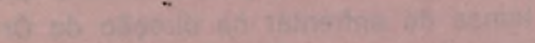

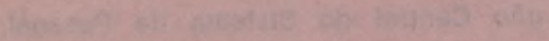

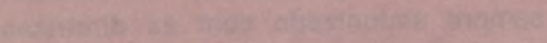

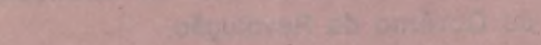

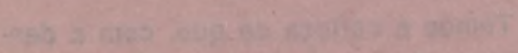

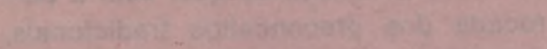

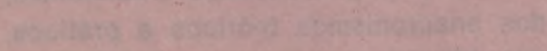

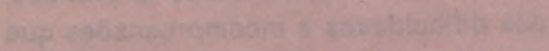

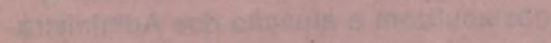

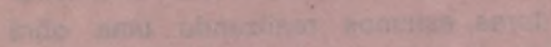

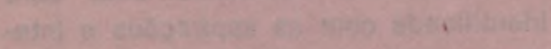

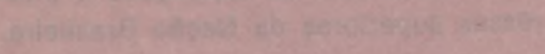

Whachour witidy

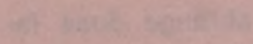

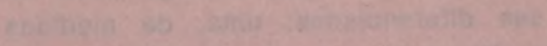

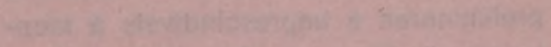

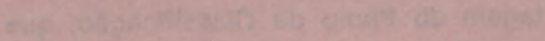

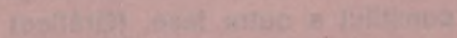

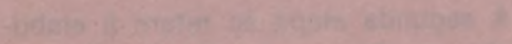

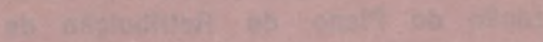

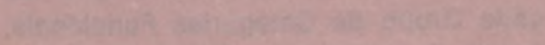

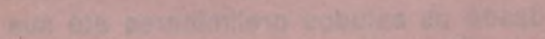

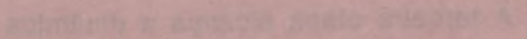

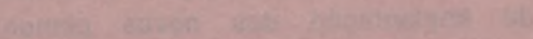

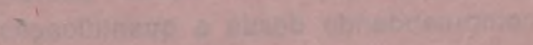

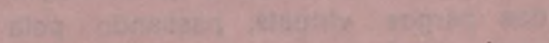

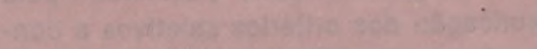

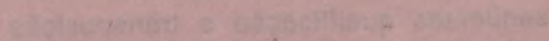

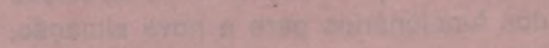

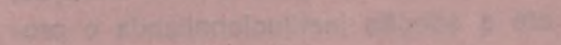

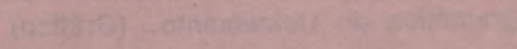

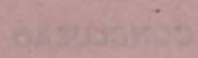

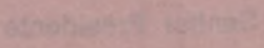
Doty

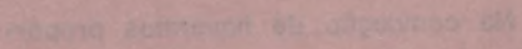

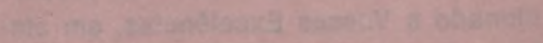

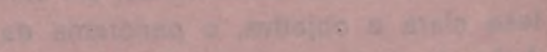

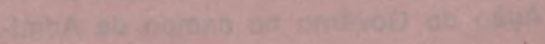

